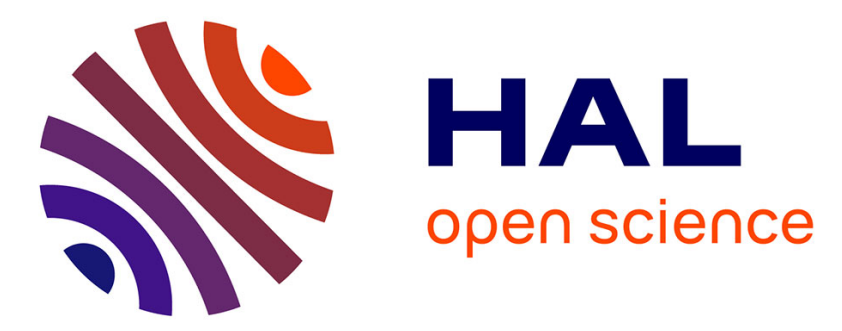

\title{
Molecular engineering to improve the charge carrier balance in single-layer silole-based OLEDs
}

Laurent Aubouy, Nolwenn Huby, Lionel Hirsch, Arie van Der Lee, Philippe

Gerbier

\section{- To cite this version:}

Laurent Aubouy, Nolwenn Huby, Lionel Hirsch, Arie van Der Lee, Philippe Gerbier. Molecular engineering to improve the charge carrier balance in single-layer silole-based OLEDs. New Journal of Chemistry, 2009, 33, pp.1290. 10.1039/b900780f . hal-00415724

\section{HAL Id: hal-00415724 \\ https://hal.science/hal-00415724}

Submitted on 17 Sep 2009

HAL is a multi-disciplinary open access archive for the deposit and dissemination of scientific research documents, whether they are published or not. The documents may come from teaching and research institutions in France or abroad, or from public or private research centers.
L'archive ouverte pluridisciplinaire HAL, est destinée au dépôt et à la diffusion de documents scientifiques de niveau recherche, publiés ou non, émanant des établissements d'enseignement et de recherche français ou étrangers, des laboratoires publics ou privés. 


\title{
Molecular engineering to improve the balance of charge carrier in single-layer silole-based OLEDs.
}

\author{
Laurent Aubouy, ${ }^{a}$ Nolwenn Huby, ${ }^{b}$ Lionel Hirsch, ${ }^{* b}$ Arie van der Lee, ${ }^{c}$ and Philippe Gerbier ${ }^{a}$
}

We report a molecular engineering study on optical, structural and electrical properties of seven silole derivates aiming at enhancing the balance of charge carrier in single-layer devices. By functionalizing two hole-transporting groups, dipyridylamine or anthracene, on the silole ring, we have investigated the influence of both entity types on the hole current. We have concluded that in 10 contrast to dipyridylamine groups, anthracene groups decrease the balance of charge carrier since the latter groups not only increase the hole current but also electron contribution. Doubling the number of hole transporting groups lead the silole $\mathbf{D}$ to become a very efficient emissive layer exhibiting threshold voltage below $3 \mathrm{~V}$ and luminous efficiency $L_{e}=0.8 \mathrm{~cd} / \mathrm{A}$ at $7 \mathrm{~V}$.

\section{${ }_{15}$ Introduction}

Organic light-emitting diodes (OLEDs) using small molecules or polymers have been intensively pursued after the initial works by Tang, Van Slyke and Burroughes ${ }^{1,2}$ because of their enormous potential in flat, flexible panels lighting and 20 displays. The search for efficient and stable new emitting materials with appropriate emission spectrum remains as one of the most active areas of these studies. Different strategies have been developed to enhance the efficiency of the devices such as the assisted singlet-triplet internal conversion and the ${ }_{25}$ balance of charge carriers in the emissive zone. Among them, the approach involving the incorporation of heavy metal complexes has attracted a great attention since it allows to obtain both very high efficiencies and white emission. ${ }^{3-8}$ On the other hand, the balance of charge carriers in the emissive 30 zone has attracted much less attention due to the development of multilayer structures as a response to this issue. ${ }^{9,}{ }^{10}$ Indeed, in organic semi-conductors, one of both charge-carriers presents a higher mobility compared to the other one. This leads to several drawbacks such as, for instance, the location 35 of the recombination zone close to an electrode, leading to a huge quenching of excitons. Therefore it is possible to overcome this problem by using PIN OLEDs structures ${ }^{11}$. Nevertheless, this approach suffers of some drawbacks due to a large number of interfaces and/or segregation phase 40 apparition. The main text of the article should appear here. Headings and subheadings should be formatted using the

${ }^{a}$ Université Montpellier 2, Institut Charles Gerhardt de Montpellier UMR 5253. CC 007, Place Eugène Bataillon ; 34095 Montpellier cedex 5, France.Fax: (+)33.(0)4.67.14.38.52 ; E-mail: gerbier@univ-montp2.fr ${ }^{b}$ Université Bordeaux 1, Laboratoire d'Intégration du Matériau au Système (IMS) - UMR 5218. Ecole Nationale Supèrieure de Chimie et de Physique de Bordeaux, 16, Avenue Pey Berland ; 33607 Pessac Cedex, France. Fax: (+)33.(0)5.40.00.66.31 ; E-mail: lionel.hirsch@imsbordeaux.fr

${ }^{c}$ Université Montpellier 2, Institut Européen des Membranes - UMR 5635 CC 047, Place Eugène Bataillon; 34095 Montpellier cedex 5, France. Fax (+)33(0)4.67.14.38.52.E-mail: avderlee@univ-montp2.fr relevant button from the "Styles" toolbar.

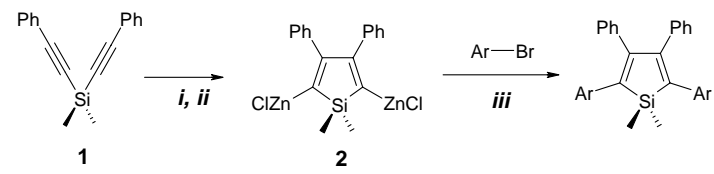

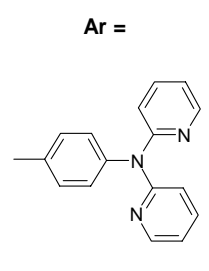

A

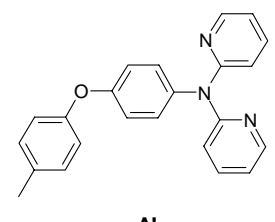

$A^{\prime}$

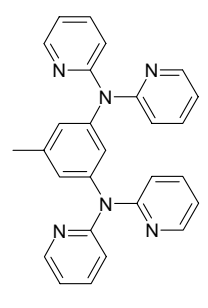

C

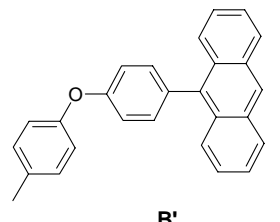

B'

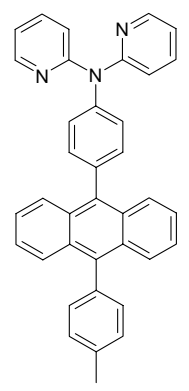

Scheme 1. Tamao's synthetic route to 2,5-difunctionnalized siloles: i) 4 equiv. LiNp, ii) 4 equiv. $\mathrm{ZnCl}_{2}$.TMEDA, iii) 2 equiv. $\mathrm{ArBr}, \mathrm{PdCl}_{2}\left(\mathrm{PPh}_{3}\right)_{2}$. 
The aim of this paper is to design a fluorescent molecule 45 able to transport both charge carriers. In this way, we focussed on silole derivatives since they appear to possess all the requirements to achieve single-layer OLEDs. The siloles ${ }^{12-}$ 15 or silacyclopentadienes are a group of five-membered silacycles that possess $\sigma^{*}-\pi^{*}$ conjugation arising from the 50 interaction between the $\sigma^{*}$ orbital of two exocyclic $\sigma$ bonds on the silicon atom and the $\pi^{*}$ orbital of the butadiene moiety. ${ }^{16}$ As a consequence, the calculated LUMO level of a silole ring is lower than those of other heterocyclopentadienes, such as pyrrole, furan, and thiophene.

${ }_{55}$ Moreover, thanks to its nonaromatic character the $\pi$-system of the silole ring is more prone to allow electron delocalization when compared with its thiophene cousins. ${ }^{17,} 18$ From a structural point of view, because of the non-coplanar structure of 2,3,4,5-tetraarylsiloles, the distances between silole cores 60 of any two adjacent molecules, even in the solid state, are far from the normal $\pi-\pi$ interaction distance (ca. 3-4 $\AA$ ). ${ }^{19}$ This gives rise to a very interesting photophysical property called aggregation-induced photoluminescence (PL) emission (AIE). ${ }^{20,}{ }^{21}$ Because of the AIE characteristics, 2,3,4,5${ }_{65}$ tetraphenylsiloles can show extremely high PL quantum yields (up to $100 \%$ ), even in a crystalline form. ${ }^{22,23}$ Thereby, 2,3,4,5-tetraphenylsiloles are excellent emitters in the fabrication of electroluminescence (EL) devices, an external
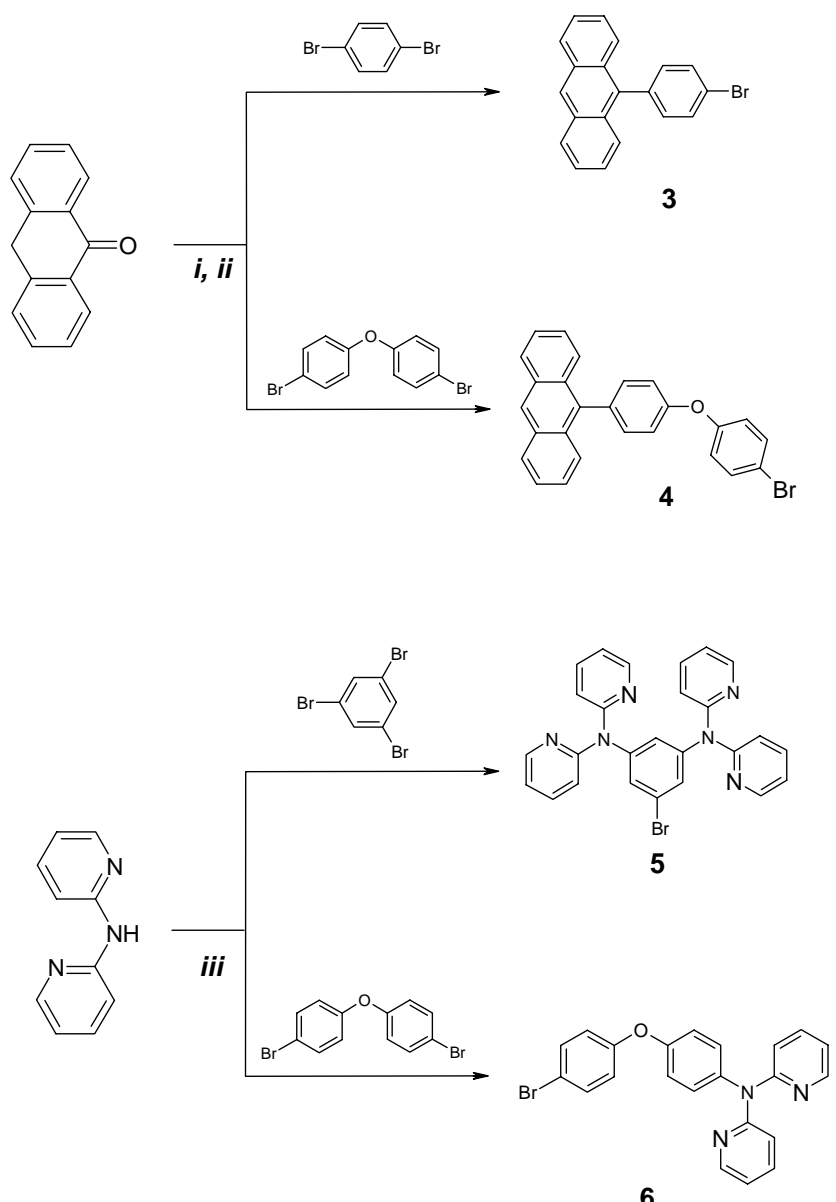

Scheme 2. Syntheses of the hole-transporting functionalities: i) 1 equiv. $n \mathrm{BuLi}$, ii) $\mathrm{MeOH}, \mathrm{HCl} 6 \mathrm{M}$, iii) $\mathrm{K}_{2} \mathrm{CO}_{3}, \mathrm{CuSO}_{4} .5 \mathrm{H}_{2} \mathrm{O}$. quantum efficiency $\left(\eta_{\mathrm{EL}}\right)$ up to $8 \%$, close to the theoretical 70 limit for a singlet emitter, was realized with such derivatives in the emissive layer. ${ }^{24,} 25$ Finally, siloles exhibit very high electron mobility, exceeding the well-known tris-(8hydroxyquinoline) aluminum (Alq3), and have been utilized as the electron-transporting layer for EL devices. ${ }^{26-28}$

75 The results presented in this paper follow previous reports concerning the silole A (Scheme 1). ${ }^{25,}{ }^{27}$ This molecule is based on a silacyclopentadiene core, which acts both as emissive and electron-transporting component, and two dipyridylamino functionalities grafted on each side, which act 80 as hole-transporting groups. ${ }^{29,} 30$ By associating those two

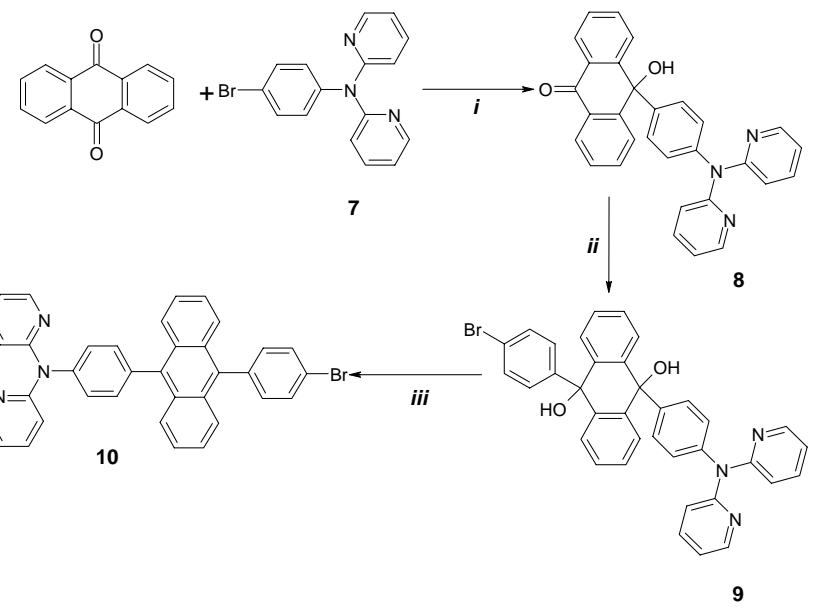

Scheme 3. Synthesis of 10: i) $\mathrm{nBuLi}$, ii) 2 equiv. 1-bromo, 4-lithiobenzene, iii) $\mathrm{NaH}_{2} \mathrm{PO}_{4}$, KI, glacial acetic acid.

functionalities, we have achieved a sufficient balance of charge to make light from single-layer OLEDs. However, the temperature dependence and the electron injection barrier dependence investigations have highlighted the weak hole ${ }_{85}$ contribution in hole-only devices that is only three orders of magnitude lower than the electron one. ${ }^{27}$ Since it may be expected that a better balance of charge should improve greatly the efficiency of the devices, we have designed the siloles shown in Schemes 1 and 3 with increasing their hole-

90 transporting properties. On the one hand, the dipyridylamino hole-transporting groups were changed by anthracenyl ones that are well known as good hole-transporting group in molecular films (siloles B and B') ${ }^{31,32}$ On the other hand, we changed the hole-carriers to electron-carriers ratio that is $1: 1$ 95 for silole E, 2:1 for siloles A, A', B, B' and 4:1 for siloles C and $\mathbf{D}$. The effect of the conjugation between electron- and hole-transporting moieties was also studied by inserting a disrupting ether bridge between the two (siloles A vs A' and B $v s$ B'). Optical and structural properties are systematically 100 correlated to the device performances in order to highlight the influence of the number of hole-transporting group on the balance of charge carriers.

\section{Results and Discussion}



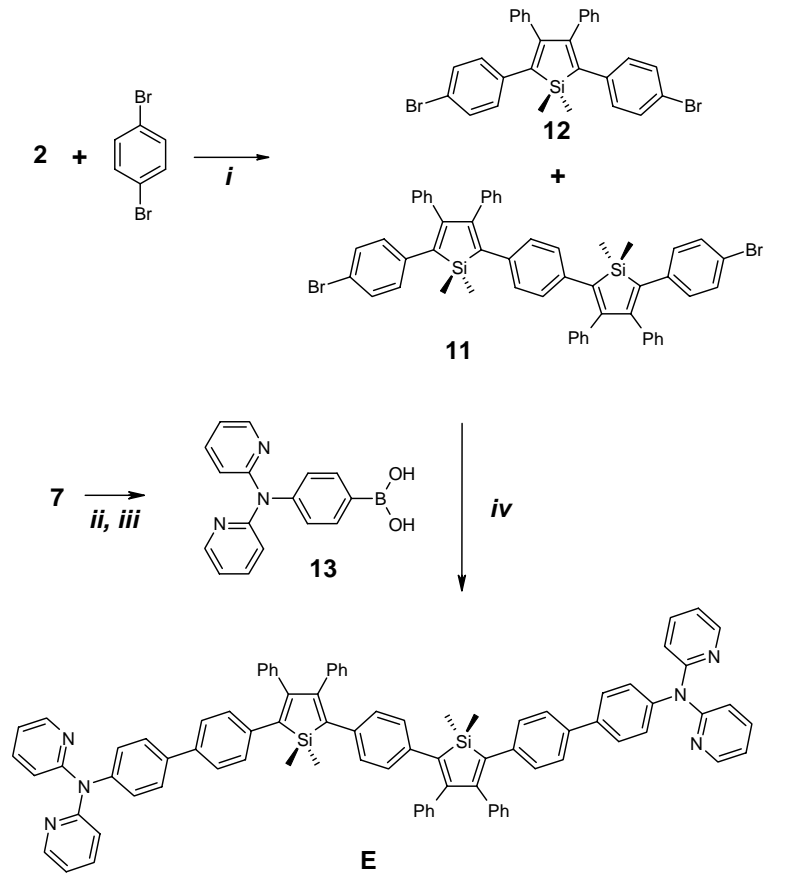

Scheme 4. Synthesis of $\mathbf{E}$ : i) $\mathrm{PdCl}_{2}\left(\mathrm{PPh}_{3}\right)_{2}$, ii) 1 equiv. $n \mathrm{BuLi}, \mathrm{B}(\mathrm{OMe})_{3}$, iii) $\mathrm{H}_{2} 0$, $\mathrm{NH}_{4} \mathrm{Cl}$, iv $) \mathrm{Pd}\left(\mathrm{PPh}_{3}\right)_{4}, \mathrm{~K}_{2} \mathrm{CO}_{3}$.

\section{(i) Syntheses}

105 The siloles A-D were conveniently prepared by the method described by Tamao and Yamaguchi ${ }^{33}$ that involves the onepot reductive intramolecular cyclization of bis(phenylethynyl)silane and the subsequent $\operatorname{Pd}(0)$-catalyzed cross-coupling reaction with the desired arylbromide (Scheme

110 1). The synthesis of 9-(4-bromophenyl)-anthracene 3 and 9[4-(4-Bromo-phenoxy)-phenyl]anthracene 4 was achieved starting from anthrone by using the procedure described by Murphy et al. ${ }^{34}$ 3,5-bis(2,2'-dipyridylamino)-bromobenzene 5 and [4-(4-bromo-phenoxy)-phenyl]di-pyridyn-2-yl-amine 6 115 were synthesized through a modification of the original Ullman's reaction. ${ }^{35,36}$ The preparation of the asymmetrically 9,10-diarylanthracene $\mathbf{1 0}$ was achieved through an adaptation of the procedure described by Smet et al.. ${ }^{37,38}$ It involves firstly the lithiation of the compound $7^{25,39}$ followed by the 120 addition of the resulting lithio derivative on anthraquinone to afford the monoadduct 8 in $43 \%$ yield. To this compound, a two-fold excess of 4-bromophenyllithium was added yielding the diol 9. The excess of 4-bromophenyllithium was necessary to react with the $\mathrm{OH}$ group present in the monoadduct 8 .

${ }_{125}$ Reduction of the latter using $\mathrm{NaH} 2 \mathrm{PO} 2$ and $\mathrm{KI}$ in refluxing acetic acid afforded $\mathbf{1 0}$ as a light yellow solid in $20 \%$ yield.

The synthesis of silole $\mathbf{E}$ involves firstly the preparation of the bis-silole derivative $\mathbf{1 1}$ through the Tamao-Yamaguchi's
130 reaction between the dizincic intermediate 2 and 1.5 equiv. of 1,4-dibromobenzene. The bis(bromophenyl)silole $\mathbf{1 2}$ which is formed along with $\mathbf{1 1}$ is easily isolated by column chromatography and will serve as starting material for other syntheses. The subsequent Suzuki coupling between 11 and 135 the boronic acid derivative $13^{39}$ afforded the expected bissilole $\mathbf{E}$ in good yield.

\section{(ii) Geometries of siloles}

The determination of the conformational preferences of 140 these molecules is of outmost importance for the understanding of their electronic behaviour. Since crystals suitable for a X-ray structure determination could only be obtained for $\mathbf{A},{ }^{40} \mathbf{B},{ }^{41}$ and $\mathbf{1 1}$, we turned to density functional theory (DFT) calculations with the B3LYP functional to 145 obtain information about the molecular conformations for the rest of siloles. ${ }^{42}$ Due to the size of the molecules, geometry optimizations without symmetry constrains were performed with the $6-31 \mathrm{G}$ basis set to the standard convergence criteria as implemented in Gaussian98. ${ }^{43}$ Such calculations were 150 followed by single point runs using a $6-31+\mathrm{G}^{*}$ basis to obtain accurate energies. Structurally characterized siloles, dipyridylamines, and diphenylethers served as benchmarks to test how well the experimentally determined geometry is reproduced by the calculations, and some relevant torsion 155 angles are collected in Table $1 .{ }^{19}$ As exemplified with $\mathbf{A}$ (Figure 1), all compounds have a propeller-like arrangement of the four phenyl rings, as found in the crystal structures, while the two methyl substituents on the silicon atom are nearly perpendicular to the mean plane of the $\mathrm{SiC}_{4}$ ring. The 160 torsion angles of the substituted phenyl rings at the 2- and 5-
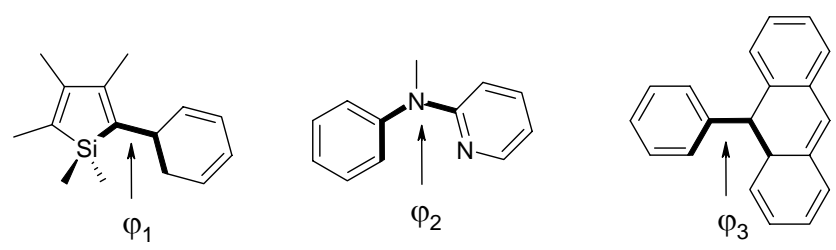

Scheme 5. Location of the torsion angles reported in table 1.

positions of the central silole ring $\left(\varphi_{1}\right)$ are in the range of what is usually observed with tetraarylsiloles (ca. 30-60 $)$.

Table 1. Torsion angles $\left[{ }^{\circ}\right]$ in siloles ${ }^{a}$

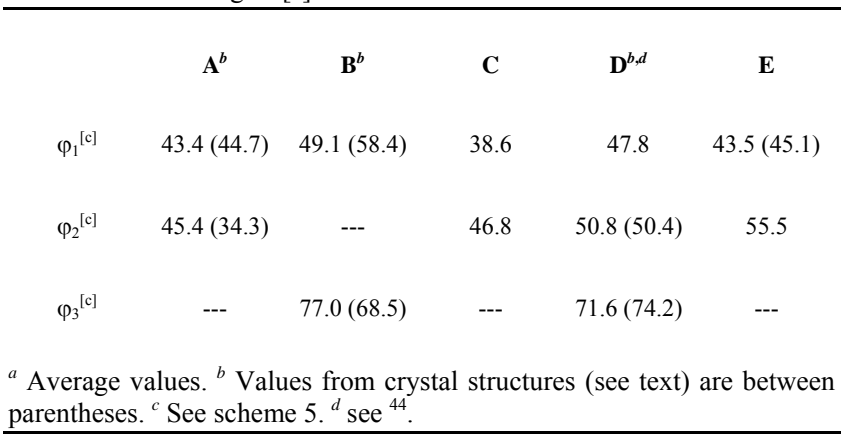



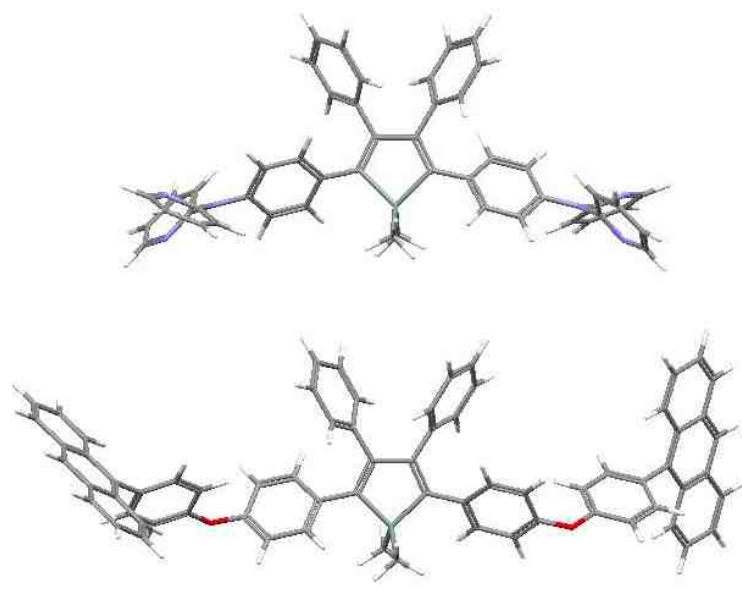

Figure 1. DFT-optimized (B3LYP-6/31G) molecular structures of siloles A (top) and B' (bottom).

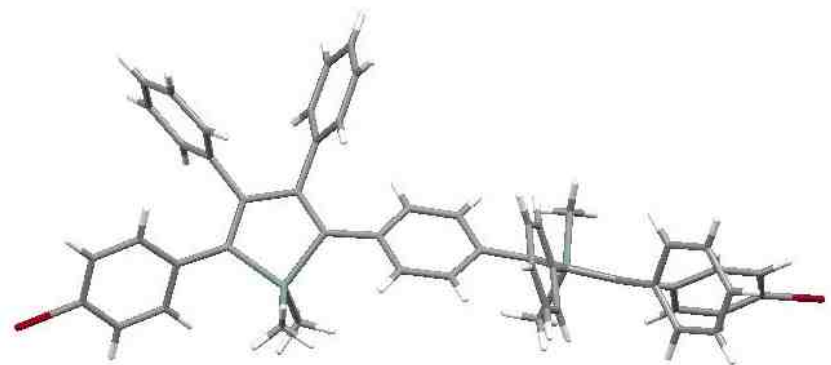

Figure 2. X-ray structure of silole 11. The $\mathrm{CH}_{2} \mathrm{Cl}_{2}$ crystallization molecule has been removed for sake of clarity.

The torsion angles between the anthracene main plane and 165 the adjacent phenyl ring $\left(\varphi_{3}\right)$ fall as well in the range of what is usually observed with related molecules $\left(\mathrm{ca} .70^{\circ}\right)$. This is expected to induce a strong reduction of the conjugation between the electron-transporting silole ring and the lateral hole-transporting groups. The same is expected when an ether

170 bridge is inserted between the two electroactive components since the plain planes of the phenyl ring on both sides of the oxygen atom are nearly perpendicular (see figure 1). Though no crystal suitable for X-ray diffraction were obtained for the bis-silole $\mathbf{E}$, we were able to solve the structure of its 175 precursor 11. This compound crystallizes along with one $\mathrm{CH}_{2} \mathrm{Cl}_{2}$ molecule in the $C 2 / c$ space group. As seen in Figure 2, the molecule possesses an axis of symmetry that passes through the middle of the central phenyl ring. The torsion angles $\varphi_{1}$ between this ring and the two adjacent siloles have a 180 value of $45.14^{\circ}$. As a result, the two silole rings are nearly perpendicular, which contrasts very strongly with the thiophene analogues that are nearly planar. This situation is also encountered in the optimized geometry of silole $\mathbf{E}$.

\section{5 (iii) Optical and electronic properties}

The UV-visible absorption, photoluminescence (PL) spectra have been measured both in solution and thin films. Electroluminescence (EL) spectra were obtained from single layer devices with a structure: ITO/PEDOT:PSS/ silole $50 \mathrm{~nm} /$ ${ }_{190} \mathrm{Ca}$. The most relevant data obtained from these spectra are collected in Table 2. Figures 3 and 4 are representative of the two behaviours that are encountered in this series of molecules. As it is seen in figure 3, compound A, A', C or $\mathbf{E}$ display a broad absorption band in the range of $368 \mathrm{~nm}$ and $195389 \mathrm{~nm}$ which is characteristic of the $\pi \rightarrow \pi^{*}$ transition in the silole ring. ${ }^{33}$ However, as it is seen in Figure 4, in the compounds $\mathbf{B}, \mathbf{B}$ ' or $\mathbf{D}$, this transition is overlapped by the well recognizable pattern of phenylanthracenes. The comparison of Figures 3 and 4 reveals that the siloles without 200 anthracene side groups behave differently than those bearing ones. In the first family (siloles A, A', $\mathbf{C}$ and $\mathbf{E}$ ) all the emission spectra are nearly superimposable whatever the excitation mode or the physical state (solution $v s$ thin film). The most important deviation is found with silole $\mathbf{C}$ in which 205 a shift of $c a .9 \mathrm{~nm}$ is found between the PL and the EL spectra (Table 2). In the second family (siloles B, B' and $\mathbf{D}$ ), the PL and EL spectra show differences both in the position of their emission maxima and in their shape, as exemplified in figure 4 with silole $\mathbf{D}$. In solution, the anthracene moieties appear to

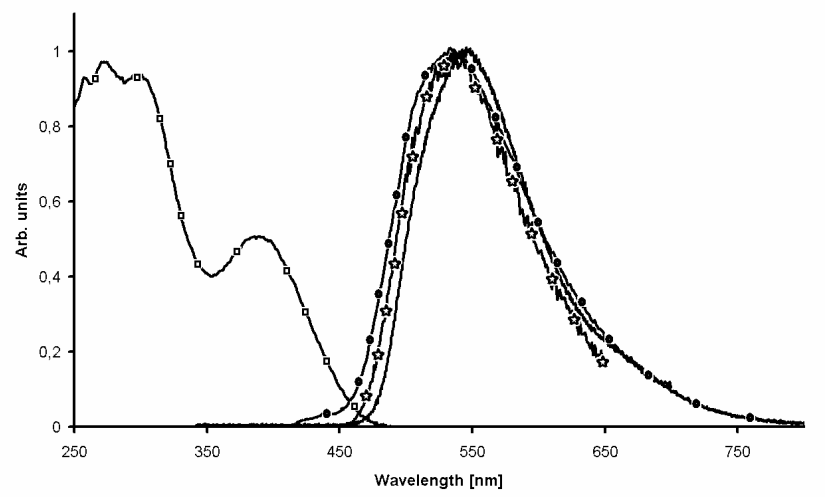

Figure 3. Normalized UV-visible ( $\square$ ), photoluminescence (in solution: $\mathbf{0}$ and thin film: $\succsim$ ) and electroluminescence $(-)$ spectra of silole A.

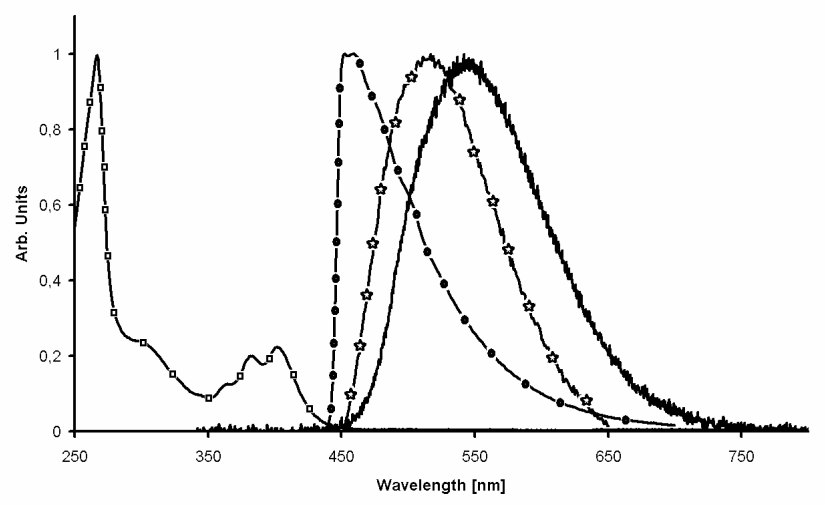

Figure 4. Normalized UV-visible ( $\square$ ), photoluminescence (in solution: $\mathbf{0}$ and thin film: $₫$ ) and electroluminescence $(-)$ spectra of silole D. 

Table 2. Main values of the optical properties (UV-Visible and
fluorescence spectra) in solution and in thin films. ${ }^{a}$

\begin{tabular}{|c|c|c|c|c|c|}
\hline Silole & $\begin{array}{c}\text { Absorption }^{b} \\
\lambda_{\max }[\mathrm{nm}]\end{array}$ & $\begin{array}{c}\mathbf{P L}^{b} \\
\lambda_{\max }[\mathrm{nm}]\end{array}$ & $\begin{array}{c}\text { Quantum } \\
\text { yield }^{c}\end{array}$ & $\begin{array}{c}\text { EL } \\
\lambda_{\max }[\mathrm{nm}]\end{array}$ & $\begin{array}{l}\text { HOMO and } \\
\text { (LUMO) } \\
\text { levels [eV] }\end{array}$ \\
\hline A & 388 (403) & $526(542)$ & 0.040 & 545 & $-5.20(-2.04)$ \\
\hline B & 389 (394) & $428(507)$ & 0.015 & 521 & $-5.39(-2.00)$ \\
\hline $\mathrm{C}$ & $379(385)$ & $503(511)$ & 0.038 & 520 & $-5.32(-1.79)$ \\
\hline $\mathrm{D}$ & 404 (437) & $455(503)$ & 0.040 & 518 & $-5.09(-1.85)$ \\
\hline E & $419(-)$ & $538(557)$ & 0.002 & 586 & $-5.11(-1.89)$ \\
\hline$A^{\prime}$ & $378(375)$ & $505(505)$ & 0.006 & 504 & $-5.00(-2.01)$ \\
\hline $\mathrm{B}^{\prime}$ & $388(392)$ & 407 (507) & 0.020 & 517 & $-5.16(-2.32)$ \\
\hline
\end{tabular}

${ }^{a}$ The values recorded with thin solid films are between parentheses. ${ }^{b}$ Measured in $\mathrm{CH}_{2} \mathrm{Cl}_{2} \cdot{ }^{c}$ Measured in solution, quantum yield relative to perylene $\left(\phi_{\mathrm{em}}=0.94\right) .{ }^{d}$ From B3LYP-6/31G* DFT calculations.

210

be mainly responsible of the emission, as attested by the vibronic coupling seen on the curves. Moreover, it is worthy to note that the Stocke's shift that is observed with this second family (ca. 20-50 nm) is substantially smaller than with the 215 first one (ca. 120-140 nm). As usually observed for the 2,3,4,5-tetraphenylsiloles, the quantum yields in solution are rather low (Table 2), the lowest value being found with $\mathbf{E}$ in which two silole rings are presents in the structure. This behaviour likely originates from resonant photon absorption ${ }_{220}$ phenomenon, since there is a substantial overlap between the absorption and the emission spectra. Moreover this observation, which indicates that the two siloles rings behave independently, is in good agreement with their perpendicular arrangement in the molecular structure (see above). 225 Interestingly, the presence of either 9-phenylanthracene or 9,10-diphenylanthracene highly fluorescent subunits (see below) in the molecular structures of siloles $\mathbf{B}, \mathbf{B}^{\prime}$ and $\mathbf{D}$ has no positive effect on their quantum yields. Along with what is observed in the fluorescence spectra, this indicates that a large 230 amount of energy is transferred from the anthracene chromophores to the silole and then released via non-radiative processes. Finally, semi-quantitative measurements of the fluorescence quantum yields on thin films have been also performed. The following sequence have been found: $\mathbf{B} \approx \mathbf{B}$ ' ${ }_{235}>\mathbf{D}>\mathbf{A}>\mathbf{A}>\mathbf{C}>\mathbf{D P A}>$ Perylene $\approx \mathbf{E}$ where DPA $(9,10-$ diphenylanthacene, $\phi_{\mathrm{em}}($ solution $\left.)=1.00\right)$ and $\mathbf{P}$ Perylene $\left(\phi_{\mathrm{em}}\right.$ $($ solution $)=0.94)^{45}$ are given for comparison. On account to the AIE phenomenon, ${ }^{20,}{ }^{21}$ the siloles display a very strong fluorescence in the solid state that exceeds both DPA and

${ }_{240}$ Perylene which possess nearly quantitative quantum yields in solution.

To better understand the optical data, we now turn to a description of the main characteristics of the HOMO and LUMO levels as calculated at the DFT level. The analysis of
245 the HOMO and LUMO wave functions shown for siloles A and $\mathbf{B}$ in Figure 5 show the typical pattern of tetraphenylsiloles. ${ }^{46,} 47$ The HOMO wavefunctions show a very similar spatial distribution with an antibonding character between the silole ring and the phenyl rings located at the 2,5250 positions. The same similarity is found with the LUMO wavefunctions in which bonding character is observed between the silole ring and the adjacent phenyl rings. The energies of the HOMO and LUMO orbitals (Table 2), which do not vary on a large extend upon modification of the 255 substituents, are in the range of what is usually reported for tetraarylsiloles. The examination of the wavefunctions calculated for siloles A' and B' (Figure 6 for B') show a nearly identical orbital distribution on the tetraphenylsilole core. However, in contrast to their parents $\mathbf{A}$ and $\mathbf{B}$, very few 260 electron probability density is found on either the dipyridylamino or the phenylanthracene moieties. This illustrates the expected disruption of the conjugation brought about by the diphenylether bridges, and the reason why the emission maximum of these two molecules is blue-shifted of $26520 \mathrm{~nm}$ when compared with their parents $\mathbf{A}$ and $\mathbf{B}$.



Figure 5. B3LYP/6-31G*-calculated highest occupied (HOMO) and lowest unoccupied (LUMO) molecular orbitals for siloles $\mathbf{A}$ and $\mathbf{B}$.

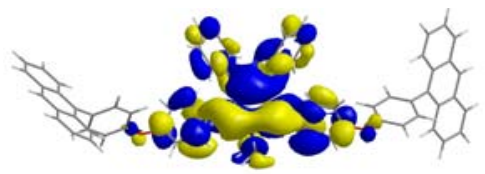

LUMO

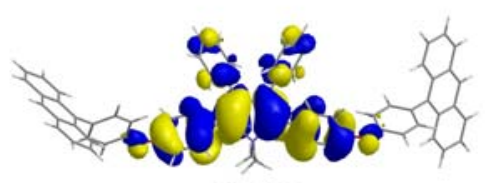

HOMO

Figure 6. B3LYP/6-31G*-calculated HOMO and LUMO molecular orbitals for silole B'.

\section{(iv) Electroluminescence properties and balance of charge} carriers

In order to study the EL properties, single layer devices have been investigated, with the following structure: $270 \mathrm{ITO} / \mathrm{PEDOT}: \mathrm{PSS} /$ silole $50 \mathrm{~nm} / \mathrm{Ca}$. The electroluminescent spectra are shown in Figure 7. As observed during the photoluminescence studies, only the silole ring contributes to the emission and device based on molecule $A$ is $20 \mathrm{~nm}$ 
redshift compared to the others. All the emissions correspond 275 to the yellow-green domain on the chromatic diagram of the

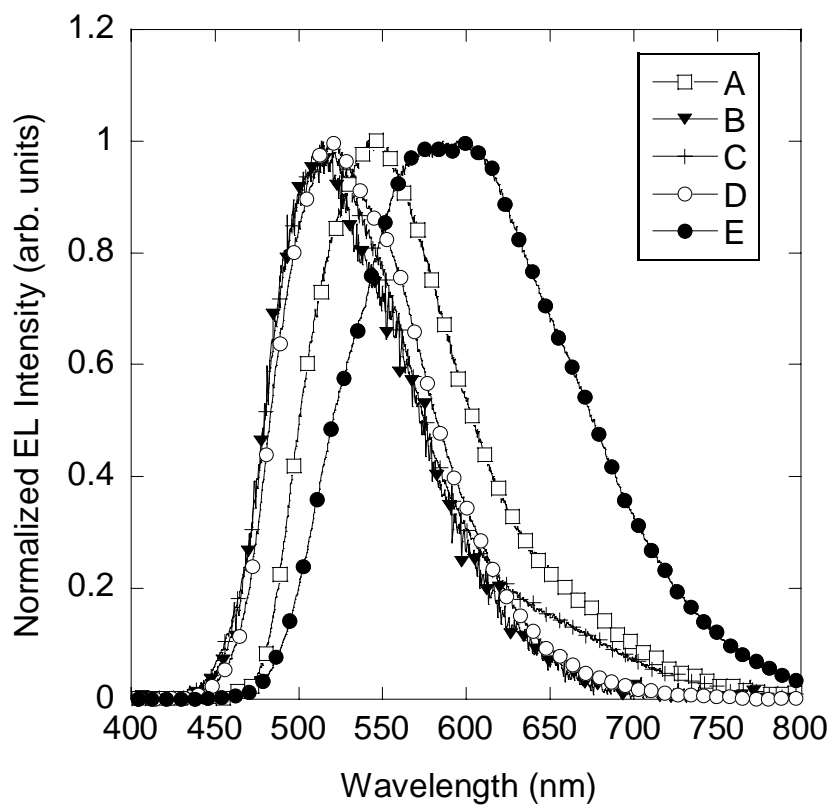

Figure 7. EL spectra from devices ITO/PEDOT:PSS/Silole $(50 \mathrm{~nm}) / \mathrm{Ca}$.

Commission Internationale de l'Eclairage. Their corresponding current density-voltage and luminance-voltage are presented in figure 3 (a) and figure 3 (b) respectively. When compared with the calculated HOMO and LUMO 280 energy levels of the siloles (see Table 2), the high work function of the anode ITO/PEDOT:PSS $(-5.2 \mathrm{eV})$ and the low one of the calcium cathode $(-2.9 \mathrm{eV})$ are suitable to favour the injection of both charge-carriers in the active layer. As a consequence, threshold voltage values generally below $4 \mathrm{~V}$ are 285 necessary to start of detection of luminance of the device (Table 3). Moreover, with the exception of siloles $\mathbf{C}$ and $\mathbf{E}$, all the molecules presented here display quite good luminous efficiencies $\left(L_{e}\right)$ for single-layer devices. In terms of performances, D exhibits the best values with a threshold 290 voltage below $3 \mathrm{~V}$ and a luminous efficiency $L_{e}$ of $0.75 \mathrm{~cd} / \mathrm{A}$ at $7 \mathrm{~V}$. At the opposite, $\mathbf{C}$ and $\mathbf{E}$ are weakly electroluminescent. Indeed, these molecules need high applied voltages to reach the same order of current density than with A, B or D.

295 To better understand the origin of these different behaviours and to try to outline the relationships that may exist between the molecular structure and the balance of charge-carriers in this series of molecules, one has to consider the factors that determine the efficiency of an OLED. 300 Actually, this may approximately be calculated by the following equation: $:^{48,49}$

$$
\eta_{\text {external }}=\gamma \cdot \eta_{\text {recomb }} \cdot \eta_{\mathrm{ST}} \cdot \eta_{\mathrm{optical}} \cdot \Phi_{\mathrm{PL}}
$$

305

where $\eta_{\text {external }}$ is the total power efficiency of the device, $\gamma$ is the balance of charge-carrier, $\eta_{\text {recomb }}$ represents the recombination probability of injected holes and electrons, $\eta_{\mathrm{ST}}$ is the ratio of singlet and triplet excitons contributing to the radiative recombination, $\eta_{\text {optical }}$ is the efficiency of the optical 310 outcoupling from the device, and $\Phi_{\mathrm{PL}}$ is the quantum yield of fluorescence of the emissive material. By spin statistics, $\eta_{\mathrm{ST}}$, which is the ratio of singlet to triplet excitons, should be $\eta_{\mathrm{ST}}=$ 0.25 , since parallel spin pairs will recombine to triplet excitons while antiparallel spin pairs will recombine to singlet 315 and triplet excitons. Thus, for fluorescent emitters, we find $\eta_{\mathrm{ST}}=0.25$, which is a severe limitation of quantum efficiency of an OLED. Concerning the optical outcoupling efficiency, a simple estimation regarding the OLED as classical optics device shows that a flat device with typical refractive index of 320 the organics layers of 1.7 , deposited on ITO/glass, achieves approximately $20 \%$ outcoupling. Therefore, the first factor that defines the efficiency of an OLED on which we can play

Table 3. The luminance (L), luminous efficiency $\left(L_{e}\right)$ and energetic efficiency $\left(R_{e}\right)$ of siloles operating in ITO/PEDOT:PSS/Silole/Ca OLEDs. ${ }^{a}$

\begin{tabular}{|c|c|c|c|c|}
\hline Silole & $\begin{array}{l}\text { Vth } \\
\text { [V] }\end{array}$ & $\underset{\left[\mathbf{c d} / \mathbf{m}^{2}\right]}{\mathbf{L}}$ & $\begin{array}{c}\mathbf{L}_{\mathrm{e}} \\
{[\mathbf{c d} / \mathbf{A}]}\end{array}$ & $\begin{array}{c}\mathbf{R}_{\mathrm{e}} \\
{[\mathbf{l m} / \mathbf{W}]}\end{array}$ \\
\hline A & 3.5 & $26(370)^{b}$ & $0.17(0.20)^{b}$ & $0.095(0.06)^{[\mathrm{b}]}$ \\
\hline B & 3.1 & $25(350)^{[\mathrm{b}]}$ & $0.16(0.18)^{[b]}$ & $0.100(0.09)^{[b]}$ \\
\hline $\mathrm{C}$ & 9 & $8(74)^{[\mathrm{cc}]}$ & $0.05(0.036)^{[\mathrm{c}]}$ & $0.012(0.015)^{[\mathrm{c}]}$ \\
\hline $\mathrm{D}$ & 2.9 & $80(1550)^{[\mathrm{c}]}$ & $0.52(0.75)^{[\mathrm{c}]}$ & $0.320(0.35)^{[\mathrm{c}]}$ \\
\hline E & 4.5 & $-(86)^{[\mathrm{c}]}$ & $-(0.09)^{[\mathrm{c}]}$ & - \\
\hline$A^{\prime}$ & 18 & $5(5)^{[\mathrm{b}]}$ & $0.03(0.03)^{[\mathrm{b}]}$ & $0.003(0.003)^{[b]}$ \\
\hline $\mathrm{B}^{\prime}$ & 4.2 & $21(290)^{[\mathrm{c}]}$ & $0.14(0 ; 19)^{[\mathrm{c}]}$ & $0.060(0.060)^{[\mathrm{c}]}$ \\
\hline
\end{tabular}

${ }^{a}$ Values measured at a current density of $20 \mathrm{~mA} / \mathrm{cm}^{2} .{ }^{b}$ Value between parentheses measured at $100 \mathrm{~mA} / \mathrm{cm}^{2} .{ }^{c}$ Value between parentheses measured at $200 \mathrm{~mA} / \mathrm{cm}^{2}$.

from a molecular engineering point of view is the balance of charge-carrier $(\gamma)$.

325 To analyze the result of molecular engineering on the silole core in terms of balance of charge carriers, one has still to take into account both the charge transport processes and the quantum yield of fluorescence in the solid state of each molecule. Concerning the first issue, at least two parameters 330 have to be taken into consideration: the orbital energy levels

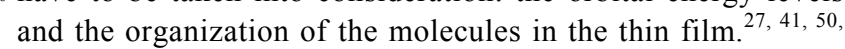
${ }^{51}$ In previous works we have studied the transport properties of siloles $\mathbf{A}$ and $\mathbf{B}{ }^{41}$ Actually, they have a very close behaviour on account to their similarities both in terms of 335 molecular organization (they form amorphous films) and in terms of energy levels and orbital distribution (see above). ${ }^{27}$, 41, 50 Therefore, it seems reasonable to set the factor $\eta_{\text {recomb }}$ in Eq. 1 to a same arbitrary value for all the series of molecules studied here. In this way, the comparison of the luminous 340 efficiencies corrected by the relative solid-state $\Phi_{P L}$ value should allow to estimate the effect of molecular engineering on the balance of charge carriers. 

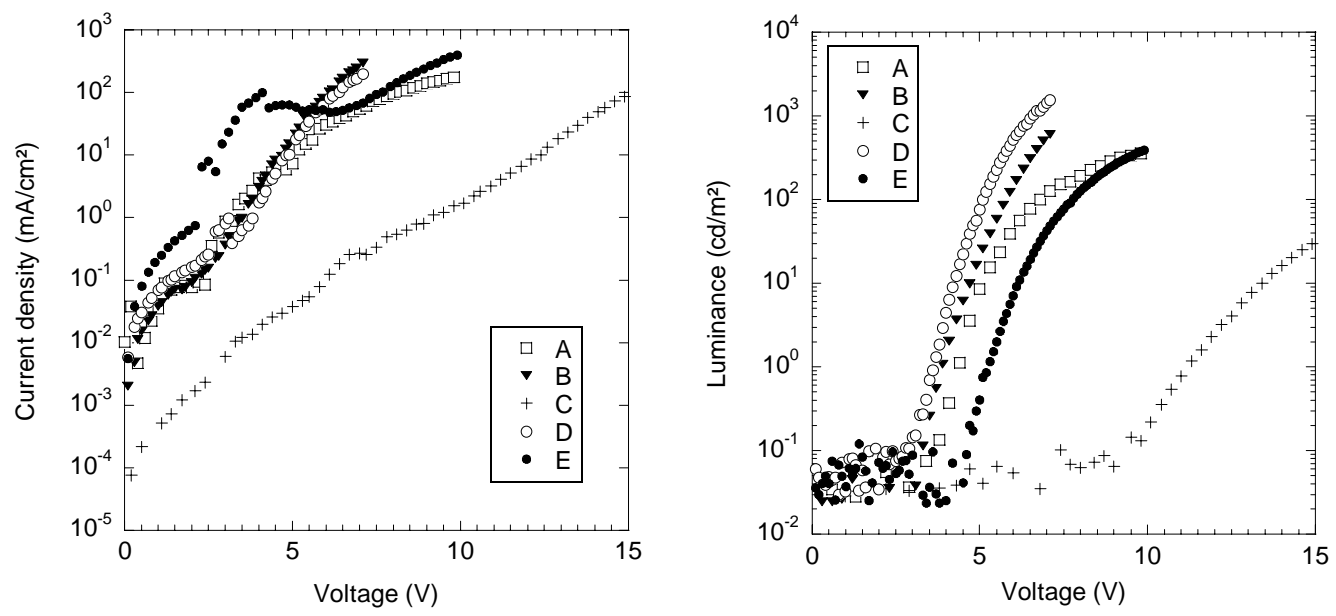

structure (Table 4).

From the examination of Table

${ }_{60} 4$, it appears that the major trend is that the more the $h^{+} / e^{-}$ratio is high, the more the balance of charges ${ }_{65}$ appears to be improved. This result is well in line with the fact that the silole ring possesses an 70 exceptional electron carrier ability 26-28 that widely exceeds the hole carrier ability of the organic groups

Figure 8. (a) Current-density-voltage characteristics for devices based on /PEDOT:PSS/Silole $(50 \mathrm{~nm}) / \mathrm{Ca}$, and (b) Corresponding luminance- 75 grafted to it. As a voltage characteristics.

From semi-quantitative measurements we have found the following sequence for the solid- state photoluminescence 345 quantum yield $\Phi_{P L}: \mathbf{B} \approx \mathbf{B}$ ' $>\mathbf{D}>\mathbf{A}>\mathbf{A}>\mathbf{C}>\mathbf{E}$. By using the procedure of normalization described in the experimental part, we have found that the photoluminescence intensity of $\mathbf{B}$ is ca. 1.5 times higher than the one of $\mathbf{D}, c a .2 .3$ times higher than the one of A, ca. 2.8 times higher than the one of $\mathbf{A}^{\mathbf{\prime}}$ and 350 more than 20 times higher than the one of $\mathbf{C}$ (the value for $\mathbf{E}$ is not given since it is of the same order than the error on the measurement). Therefore, the ratio $\mathrm{L}_{\mathrm{e}}$ over $\Phi_{P L}$, should give a good indication on the correlation between the balance of charge carriers in the device and the hole carrier moieties $\left(h^{+}\right.$: 355 dipryridylamino or anthracenyl side-groups) over the electron carrier moieties ( $e^{-}$: silole ring) present in the molecular

Table 4.. The luminous efficiency $\left(\mathrm{L}_{\mathrm{e}}\right)$, relative solid-state PL quantum yield $\left(\Phi_{\mathrm{PL}}\right)$ and the hole carrier to the electron carrier formal ratio $\left(h^{+} / e^{-}\right)$ of siloles operating in ITO/PEDOT:PSS/Silole/Ca OLEDs.

$\begin{array}{ccccc}\text { Silole } & \begin{array}{c}\mathbf{L}_{\mathbf{e}}{ }^{a} \\ {[\mathbf{c d} / \mathbf{A}]}\end{array} & \begin{array}{c}\text { Relative solid- } \\ \text { state } \Phi_{\mathrm{PL}}\end{array} & \begin{array}{c}\mathbf{L}_{\mathrm{e}} / \Phi_{\mathrm{PL}} \\ {[\mathbf{c d} / \mathbf{A}]}\end{array} & \boldsymbol{h}^{+} / \boldsymbol{e}^{-\boldsymbol{b}} \\ \mathrm{A} & 0.17 & 0.44 & 0.39 & 2 \\ \text { B } & 0.16 & 1.00 & 0.16 & 2 \\ \text { C } & 0.05 & <0.05 & >1.00 & 4 \\ \text { D } & 0.52 & 0.67 & 0.78 & 4 \\ \text { E } & - & - & - & 1 \\ \text { A' } & 0.03 & 0.36 & 0.08 & 2 \\ \text { B' } & 0.14 & 1.00 & 0.14 & 2\end{array}$

\footnotetext{
${ }^{a}$ Values measured at a current density of $20 \mathrm{~mA} / \mathrm{cm}^{2} .{ }^{b}$ A silole ring accounts for $1 e^{-}$whereas either an anthracenyl or a dipyridylamino sidegroup accounts for $1 h^{+}$..
} number of hole-transporting groups are needed to correct the balance of charge. Therefore, the silole $\mathbf{D}$ in which the $h^{+} / e^{-}$ ratio is equal to 4 displays the best luminous efficiency. In the 380 case of the silole $\mathbf{C}$, in spite of a similar ratio, the performances are disappointing since luminance and efficiencies (see table 2) are one order of magnitude lower than $\mathbf{A}$ and $\mathbf{B}$ at $20 \mathrm{~mA} / \mathrm{cm}^{2}$. Moreover the current density is considerably lowered than the one observed with the other 385 molecules at a considered applied voltage. This phenomenon may be attributed to two main reasons: $i$ ) this silole posses a weak solid-state $\Phi_{P L}$ when compared to D, and ii) the four dypirydilamino groups generate a strong steric hindrance which disfavours the electron transfert between the silole 390 rings in the device.

The comparison of siloles $\mathbf{A}$ and $\mathbf{B}$ allows in which the $h^{+}$ $/ e^{-}$ratio is equal to 2 allows us to estimate the relative ability of the side-group to transport holes. They are both 395 equivalently efficient in OLEDs but $\mathbf{A}$ is characterized by a $\mathrm{L}_{\mathrm{e}}$ $/ \Phi_{P L}$ ratio of 0.39 whereas the one of $\mathbf{B}$ that is 0.16 . In other words, the dipyridylamino groups appear to be more efficient than anthracenyl ones as hole carriers to correct the balance of charges in silole-based devices. This may originates from the 400 fact that anthracene entities not only enhance the holes current compared to the dipyridylamine ones, but also increase the electron current, leading to a smallest correction of the balance of charge carriers. The comparison of siloles A, A', B and $\mathbf{B}^{\prime}$ allows us now to evaluate the importance of the 405 conjugation between both the charge carriers since the presence of the diphenyl bridge has been shown to isolate both the moieties from an electronic point of view (see above). The disruption of the conjugation in silole $\mathbf{A}^{\prime}$ is accompanied by a marked decrease of the efficiency when 410 compared to A, while the solid-state $\Phi_{P L}$ of both are close enough. In contrast to that, the same modification only weakly affects the efficiency of the devices based on siloles $\mathbf{B}$ and $\mathbf{B}$ '.

\section{Conclusions}


In this paper we showed that the balance of charge carriers can be 415 improved by assembling different entities. The central silole ring has been functionalized by hole transporting groups. Two solutions have been investigated. On the one hand, dipyridylamino have been compared to anthracene groups. Performances had not been improved due to enhancement of both

420 charge carriers transport. On the other hand, two new molecules have been synthesized containing four hole transporting groups for one silole ring. Finally, the energetic efficiencies have been enhanced by a factor six using the same device structure using suited hole transporting groups and appropriate grafted positions.

\section{${ }_{425}$ Experimental}

\section{General methods and device performance measurements}

Solvents were distilled prior to use. THF and ether were dried over sodium/benzophenone, and distilled under Argon. All the reactions were carried out under argon atmosphere. ${ }^{1} \mathrm{H}$, ${ }_{430}{ }^{13} \mathrm{C}$ and ${ }^{29} \mathrm{Si}$ NMR spectra were recorded on a Bruker Advance 200 DPX spectrometer, the FT-IR spectra on a Thermo Nicolet Avatar 320 spectrometer, the UV-visible spectra on a Secomam Anthelie instrument and the MS spectra on a Jeol JMS-DX 300 spectrometer. I-V characteristics were recorded 435 with a Keithley 2400 Sourcemeter, L-V with a photodiode placed under the OLED and coupled to an HP multimeter. Electroluminescence spectra were measured using an Ocean Optics PC2000 CCD spectrometer. All electroluminescent devices were kept are characterized in a glove box under 440 nitrogen. Fluorescence spectra in thin film were recorded with a Edinburgh Instruments Ltd spectrofluorimeter. Absorption spectra in thin film were realized with an UV-visible SAFAS Monaco 190 DES spectrometer. Current-voltage (I-V) characteristics were recorded using a Keithley 4200

${ }_{445}$ Semiconductor analyser and luminance-voltage $(\mathrm{L}-\mathrm{V})$ with a photodiode calibrated with a Minolta CS-100 luminancemeter. Electroluminescence (EL) spectra were measured using an Ocean Optics HR2000 CCD spectrometer. All electroluminescent devices were fabricated and characterized 450 in a glove box under nitrogen with [02] and [H2O] less than $0.1 \mathrm{ppm}$. The semi-quantitative solid state quantum yields have been measured on evaporated films of the same thickness and corrected by the corresponding absorption coefficient at the excitation wavelength $(380 \mathrm{~nm})$. In order to 455 compare materials, cares have been taken for experimental conditions. Spectrofluorimetre parameters were kept unchanged from a sample to another, thickness of the thin films were the same and the fluorescence spectrum of each molecule has been corrected by the corresponding absorption 460 coefficient at the excitation wavelength. An excitation wavelength at $380 \mathrm{~nm}$ has been selected, since all maxima absorption bands are localized in this domain.

\section{X-ray diffraction}

465 The diffraction intensities for silole $\mathbf{1 1}$ were collected at the joint X-ray Scattering Service of the Institut Charles Gerhardt and the Institut Européen des Membranes of the University of Montpellier II, France, at $175 \mathrm{~K}$ using an Oxford Diffraction Xcalibur-I diffractometer. The structure
470 was solved by ab-initio (charge-flipping) methods using SUPERFLIP $^{52}$ and refined by least-squares methods on $\mathrm{F}$ using CRYSTALS, ${ }^{53}$ against $|F|$ on data having $I>2 \sigma(I) ; R$ factors are based on these data. Hydrogen atoms were located from difference Fourier synthesis. The $\mathrm{CH}_{2} \mathrm{Cl}_{2}$ crystallization 475 molecule was found to be heavily disordered. Two carbon positions and seven chlorine position were found. The total site occupancy of the carbon positions were strongly restrained to 1 and that of the chlorine positions to 2 . Restraints were also put on the $\mathrm{U}_{\text {iso }}$ parameters of carbon and 480 chlorine in order to have them approximately equal. No attempts were made to place the proton sites for the two solvent carbon atoms. Basic structural data for silole $\mathbf{1 1}$ $\left(\mathrm{C}_{27} \mathrm{H}_{22} \mathrm{BrSi}, \mathrm{CH}_{2} \mathrm{Cl}_{2}\right.$; two solvent hydrogens not placed): $a=13.8694(8) \AA, b=14.3213(8) \AA, c=26.3741(14) \AA, \alpha=90^{\circ}$, ${ }_{485} \beta=98.256(4)^{\circ}, \gamma=90^{\circ}, V=5184.4(5) \AA^{3}$, space group $C 2_{1} / c$, 50775 reflections measured, 3634 independent reflections with $I>2 \sigma(I)$ used for refinement with 307 parameters and two restraints. $R=0.0391$. $w R=0.0383$. Full details can be found in the accompanying cif-file.

\section{Device fabrication}

Devices of $c a .10 \mathrm{~mm}^{2}$ were fabricated on ITO-coated glass substrates (Merck, thickness $\approx 115 \mathrm{~nm}$, sheet resistance $\rho \approx 17 \Omega / \square$ ). After the cleaning process in trichloroethylene, ethanol and deionised water, an UV-ozone treatment was ${ }_{495}$ performed during $15 \mathrm{~min}$. Then, a $50 \mathrm{~nm}$-thick layer of PEDOT-PSS was spun coated at $5000 \mathrm{rpm}$ on top of ITO and baked at $80^{\circ} \mathrm{C}$ for about 1 hour. PEDOT-PSS is a conducting polymer, acting as a buffer, in reducing short circuit problems induced by the ITO roughness. It weakly increases the work500 function of the anode and acts as a barrier to oxygen and indium diffusion from ITO. ${ }^{54}$ On the PEDOT-PSS layer, the organic compounds as well as the cathodes were thermally evaporated under secondary vacuum $\left(10^{-6} \mathrm{mbar}\right)$. The deposition rate of the silole layer was set at about $1 \mathrm{~nm} / \mathrm{s}$ with ${ }_{505}$ a thickness of $50 \mathrm{~nm}$ measured in situ using a quartz balance and ex situ using a Tencor AS-IQ profilometer. Finally, a 80 nm-thick calcium layer capped by $100 \mathrm{~nm}$ thick aluminium layer were evaporated through a shadow mask on top of the silole derivative. Each step of their preparation and 510 characterization took place in glove box under inert atmosphere.

\section{Preparation of 9-[4-(4-Bromo-phenoxy)-phenyl]anthracene} (4)

515 A solution of n-BuLi $2.5 \mathrm{M}$ in hexane $(7.7 \mathrm{~mL}, 19 \mathrm{mmol})$ was added to an ethereal solution $(70 \mathrm{~mL})$ of 4,4'dibromodiphenylether $(6.25 \mathrm{~g}, 19 \mathrm{mmol})$ cooled at -78 ${ }^{\circ} \mathrm{C}$. The reaction mixture was left under stirring for $0.5 \mathrm{~h}$ at this temperature and anthrone was added by small portions ( 3 $\left.{ }_{520} \mathrm{~g}, 15 \mathrm{mmol}\right)$. This mixture was left under stirring for $3 \mathrm{~h}$ at $78^{\circ} \mathrm{C}$ and the temperature is allowed to reach slowly the room temperature. An aqueous solution of $\mathrm{HCl}(0.5 M)$ was then added to the reaction mixture until a $\mathrm{pH}$ of 4-5 was reached and extracted with $\mathrm{Et}_{2} \mathrm{O}$. After the usual processing, the ${ }_{525}$ resulting residue was subjected to a silicagel column chromatography $\left(\mathrm{CH}_{2} \mathrm{Cl}_{2}\right.$ /pentane : 10/90) to give 4 as a 
white-yellow solid (yield : $50 \%$ ). Mp: $149{ }^{\circ} \mathrm{C} .{ }^{1} \mathrm{H}$ NMR $\left(\mathrm{CDCl}_{3}, \delta, \mathrm{ppm}\right): 8.54(\mathrm{~s}, 1 \mathrm{H}), 8.09\left(\mathrm{~d},{ }^{3} J(\mathrm{H}, \mathrm{H})=8,2 \mathrm{H}\right), 7.75$ $\left(\mathrm{d},{ }^{3} J(\mathrm{H}, \mathrm{H})=8 \mathrm{~Hz}, 1 \mathrm{H}\right), 7.60-7.37(\mathrm{~m}, 8 \mathrm{H}), 7.23\left(\mathrm{~d},{ }^{3} J(\mathrm{H}, \mathrm{H})=\right.$ $5309 \mathrm{~Hz}, 2 \mathrm{H}), 7.12\left(\mathrm{~d},{ }^{3} \mathrm{~J}(\mathrm{H}, \mathrm{H})=9 \mathrm{~Hz}, 2 \mathrm{H}\right) .{ }^{13} \mathrm{C} \mathrm{NMR}\left(\mathrm{CDCl}_{3}, \delta\right.$, ppm) : 158.81, 156.71, 136.56, $134.35133 .27,133.15$, $131.79,130.79,128.83,127.13,127.07,125.86,125.55$, 121.33, 119.01, 116.45. . HRMS (FAB+, m-nitrobenzyl alcohol matrix) $m / z$ : calcd for $[M+\mathrm{H}]^{+} \mathrm{C}_{26} \mathrm{H}_{17} \mathrm{BrO}: 424.0463$; 535 found : 424.0456 .

\section{Preparation of [4-(4-bromo-phenoxy)-phenyl]di-pyridyn-2-yl- amine (6)}

A mixture of 4,4'-dibromodiphenylether (7.14 g, 21.7 mmol), di-2-pyridylamine $(1.50 \mathrm{~g}, 8.70 \mathrm{mmol}), \mathrm{K}_{2} \mathrm{CO}_{3}(1.40$ $540 \mathrm{~g}, 10.4 \mathrm{mmol})$ and $\mathrm{CuSO}_{4} .5 \mathrm{H}_{2} \mathrm{O}(0.217 \mathrm{~g}, 0.87 \mathrm{mmol})$ in water $(20 \mathrm{~mL})$ and $\mathrm{CH}_{2} \mathrm{Cl}_{2}(100 \mathrm{~mL})$ was stirred well and evaporated to dryness in vacuum. The mixture was ground in a mortar and 3-5 drops of $\mathrm{CH}_{2} \mathrm{Cl}_{2}$ were added to this mixture. The mixture was heated in a schlenk tube at $210{ }^{\circ} \mathrm{C}$ for $6 \mathrm{~h}$.

${ }_{545} \mathrm{After}$ being cooled at room temperature, the mixture was dissolved in $\mathrm{CH}_{2} \mathrm{Cl}_{2}(100 \mathrm{~mL})$ and water $(100 \mathrm{~mL})$ and extracted. After evaporation of the solvent, the residue was subjected to column chromatography $\mathrm{CH}_{2} \mathrm{Cl}_{2} / \mathrm{THF}$ (95/5) to afford compound 6 as a white solid (yield: 80\%).\%). Mp: 102 ${ }_{550}^{\circ}{ }^{\circ} \mathrm{C} .{ }^{1} \mathrm{H}$ NMR $\left(\mathrm{CDCl}_{3}, \delta, \mathrm{ppm}\right): 8.33\left(\mathrm{dd},{ }^{3} \mathrm{~J}(\mathrm{H}, \mathrm{H})=6,{ }^{3} \mathrm{~J}(\mathrm{H}, \mathrm{H})\right.$ $=2 \mathrm{~Hz}, 2 \mathrm{H}), 7.62\left(\mathrm{td},{ }^{3} \mathrm{~J}(\mathrm{H}, \mathrm{H})=7,{ }^{3} \mathrm{~J}(\mathrm{H}, \mathrm{H})=2 \mathrm{~Hz}, 2 \mathrm{H}\right), 7.47$ $\left(\mathrm{d},{ }^{3} J(\mathrm{H}, \mathrm{H})=9 \mathrm{~Hz}, 2 \mathrm{H}\right), 7.21\left(\mathrm{~d},{ }^{3} J(\mathrm{H}, \mathrm{H})=6 \mathrm{~Hz}, 2 \mathrm{H}\right), 7.00-$ $6.81(\mathrm{~m}, 8 \mathrm{H}) .{ }^{13} \mathrm{C} \mathrm{NMR}\left(\mathrm{CDCl}_{3}, \delta, \mathrm{ppm}\right): 157.99,156.17$, $154.50,148.50,148.47,140.33,137.63,128.92,120.82$,

${ }_{555} 119.84,118.15,116.71,115.95$. HRMS (FAB+, m-nitrobenzyl alcohol matrix) $\mathrm{m} / \mathrm{z}$ : calcd for $[M+\mathrm{H}]^{+} \quad \mathrm{C}_{22} \mathrm{H}_{16} \mathrm{BrN}_{3} \mathrm{O}$ : 418.0550; found: 418.0547 .

\section{Preparation of [4-(di-pyridin-2-yl-amino)-phenyl]-10- hydroxy-anthracen-9-one (8)}

${ }_{560}$ A solution of $\mathrm{n}$-BuLi $2.5 \mathrm{M}$ in hexane $(10.5 \mathrm{~mL}, 26 \mathrm{mmol})$ was added to a THF solution $(100 \mathrm{~mL})$ of $4-\left(2,2^{2}-\right.$ dipyridylamino)bromobenzene $7^{25}, 39$ ( $\left.7 \mathrm{~g}, 21 \mathrm{mmol}\right)$ THF cooled at $-78{ }^{\circ} \mathrm{C}$. The reaction mixture was left under stirring for $1 \mathrm{~h}$ at this temperature. A THF solution $(150 \mathrm{~mL})$ of 565 anthraquinone $(8.73 \mathrm{~g}, 42 \mathrm{mmol})$ was then added to this mixture and left under stirring for $8 \mathrm{~h}$ while allowing the temperature reach slowly the room temperature. An aqueous solution of $\mathrm{HCl}(1 M)$ was then added to the reaction mixture until a $\mathrm{pH}$ of 4-5 was reached and extracted with $\mathrm{Et}_{2} \mathrm{O}$. After

570 the usual processing, the resulting residue was subjected to a silicagel column chromatography $\left(\mathrm{CH}_{2} \mathrm{Cl}_{2} / \mathrm{THF}\right.$ gradient: $97 / 3$ to $90 / 10$ ) to give 8 as a light yellow powder (yield: $43 \%$ ). Mp: $265-267{ }^{\circ} \mathrm{C} .{ }^{1} \mathrm{H}$ NMR $\left(\mathrm{CDCl}_{3}, \delta, \mathrm{ppm}\right)$ : 8.35-8.09 (m, $4 \mathrm{H}), 7.77\left(\mathrm{dd},{ }^{3} J(\mathrm{H}, \mathrm{H})=8,{ }^{3} J(\mathrm{H}, \mathrm{H})=1 \mathrm{~Hz}, 2 \mathrm{H}\right), 7.62(\mathrm{td}$, $\left.{ }_{575}^{3} \mathrm{~J}(\mathrm{H}, \mathrm{H})=7,{ }^{3} \mathrm{~J}(\mathrm{H}, \mathrm{H})=2 \mathrm{~Hz}, 2 \mathrm{H}\right), 7.58-7.48(\mathrm{~m}, 4 \mathrm{H}), 7.37(\mathrm{~d}$, $\left.{ }^{3} J(\mathrm{H}, \mathrm{H})=9 \mathrm{~Hz}, 2 \mathrm{H}\right), 7.10\left(\mathrm{~d},{ }^{3} J(\mathrm{H}, \mathrm{H})=9 \mathrm{~Hz}, 2 \mathrm{H}\right), 7.00-6.89$ $(\mathrm{m}, 4 \mathrm{H}), 2.93(\mathrm{~s}, 1 \mathrm{H}) .{ }^{13} \mathrm{C} \mathrm{NMR}\left(\mathrm{CDCl}_{3}, \delta, \mathrm{ppm}\right): 182.32$, $151.40,148.71,147.94,138.45,134.53,130.75,130.36$, $128.71,128.60,127.37,127.21,126.65,118.83,117.04$, 580 116.57, 73.5. HRMS (FAB+, m-nitrobenzyl alcohol matrix) $\mathrm{m} / \mathrm{z}$ : calcd for $[M+\mathrm{H}]^{+} \mathrm{C}_{30} \mathrm{H}_{22} \mathrm{~N}_{3} \mathrm{O}_{2}$ : 455.5227; found: 456.1704 .
Preparation of (4-[10-(4-Bromo-phenyl)-anthracen-9-yl]phenyl)di-pyridin-2-yl-amine (10)

585 A solution of n-BuLi $2.5 \mathrm{M}$ in hexane $(10 \mathrm{~mL}, 25 \mathrm{mmol})$ was added to a THF solution $(50 \mathrm{~mL})$ of 1,4-dibromobenzene $(5.92 \mathrm{~g}, 25 \mathrm{mmol})$ cooled at $-78{ }^{\circ} \mathrm{C}$. The reaction mixture was left under stirring for $1 \mathrm{~h}$ at this temperature and added via a cannula to a THF solution $(100 \mathrm{~mL})$ of $8(3.26 \mathrm{~g}, 7.1 \mathrm{mmol})$ 590 also cooled at $-78{ }^{\circ} \mathrm{C}$. This mixture was left under stirring for $8 \mathrm{~h}$ while allowing the temperature reach slowly the room temperature, then treated with aqueous $\mathrm{HCl}(1 M)$ to $\mathrm{pH} 4-5$ and extracted with ether. The combined organic layers are dried over $\mathrm{MgSO}_{4}$ and evaporated under vacuum to afford 595 compound $\mathbf{9}$ as a viscous oil. The residue was then dissolved in glacial acetic acid $(60 \mathrm{~mL})$, treated with $\mathrm{NaH}_{2} \mathrm{PO}_{4}(8.44 \mathrm{~g}$, $95 \mathrm{mmol})$ and $\mathrm{KI}$ (4.22 g, $25 \mathrm{mmol})$, and heated to reflux for $20 \mathrm{~min}$. After cooling, the reaction mixture was treated with cold water $(300 \mathrm{~mL})$ and extracted with $\mathrm{CH}_{2} \mathrm{Cl}_{2}$. After the 600 usual processing, the resulting residue was subjected to a silicagel column chromatography $\left(\mathrm{CH}_{2} \mathrm{Cl}_{2} / \mathrm{MeOH}\right.$ : $\left.99 / 1\right)$ to give 10 as a light yellow powder (yield: $20 \%$ ). Mp: $267{ }^{\circ} \mathrm{C}$. ${ }^{1} \mathrm{H}$ NMR $\left(\mathrm{CDCl}_{3}, \delta, \mathrm{ppm}\right): 8.42\left(\mathrm{dd},{ }^{3} J(\mathrm{H}, \mathrm{H})=6,{ }^{3} \mathrm{~J}(\mathrm{H}, \mathrm{H})=2\right.$ $\mathrm{Hz}, 2 \mathrm{H}), 7.93-7.62(\mathrm{~m}, 8 \mathrm{H}), 7.53-7.39(\mathrm{~m}, 10 \mathrm{H}), 7.21(\mathrm{~d}$, $\left.{ }_{605}^{3} J(\mathrm{H}, \mathrm{H})=7 \mathrm{~Hz}, 2 \mathrm{H}\right), 7.08\left(\mathrm{td},{ }^{3} J(\mathrm{H}, \mathrm{H})=7,{ }^{3} \mathrm{~J}(\mathrm{H}, \mathrm{H})=2 \mathrm{~Hz}\right.$, $2 \mathrm{H}) .{ }^{13} \mathrm{C} \mathrm{NMR}\left(\mathrm{CDCl}_{3}, \delta, \mathrm{ppm}\right): 158.66,148.85,144.99$, $138.46,138.05,136.04,135.86,133.49,132.73,132.06$, $130.31,130.16,127.39,127.07,126.95,125.73,125.59$, 122.05, 118.86, 117.81, 116.41. HRMS (FAB+, m-nitrobenzyl ${ }_{610}$ alcohol matrix) $\mathrm{m} / \mathrm{z}$ : calcd for $[M+\mathrm{H}]^{+} \mathrm{C}_{36} \mathrm{H}_{24} \mathrm{~N}_{3} \mathrm{Br}$ : 577.5097; found: 578.1204 .

Preparation of 2-[4-(5-(4-bromo-phenyl)-1,1-dimethyl-3,4diphenyl)silol-2-yl)phenyl)-5-(4-bromo-phenyl)-1,1-dimethyl3,4-diphenyl-silole (11)

615 A mixture of lithium $(0.055 \mathrm{~g}, 8 \mathrm{mmol})$ and naphthalene $(1.03 \mathrm{~g}, 8 \mathrm{mmol})$ in THF $(15 \mathrm{~mL})$ was stirred at room temperature under argon for $5 \mathrm{~h}$ to form a deep green solution of lithiumnaphthalenide. To the this mixture was added bis(phenylethynyl)dimethylsilane $1(0.50 \mathrm{~g}, 2 \mathrm{mmol})$ in THF ${ }_{620}(10 \mathrm{~mL})$. After stirring for $10 \mathrm{~min}$, the reaction mixture was cooled to $0{ }^{\circ} \mathrm{C}$ and $\left[\mathrm{ZnCl}_{2}\right.$ (tmen) $]$ (tmen $=N, N, N^{\prime}, N^{\prime}-$ tetramethylenediamine) $(2.01 \mathrm{~g}, 8 \mathrm{mmol})$ was added, followed by an addition of THF $(20 \mathrm{~mL})$. After stirring for an hour at room temperature, a solution of 1,4-dibromobenzene $(0.80 \mathrm{~g}$, $\left.{ }_{625} 34 \mathrm{mmol}\right)$ in THF $(20 \mathrm{~mL})$ and $\left[\mathrm{PdCl}_{2}\left(\mathrm{PPh}_{3}\right)_{2}\right](0.10 \mathrm{~g}, 0.13$ mmol) were successively added. The mixture was heated under reflux and stirred for $20 \mathrm{~h}$. After hydrolysis by water, the mixture was extracted with $\mathrm{Et}_{2} \mathrm{O}$. After evaporation of the solvents, the resulting residue was subjected to a silicagel 630 column chromatography (pentane $/ \mathrm{CH}_{2} \mathrm{Cl}_{2}: 95 / 5$ ) to yield $\mathbf{1 1}$ and the silole $\mathbf{1 2}$ as separate solids. The siloles were each recrystallized from a hexane/ $\mathrm{CH}_{2} \mathrm{Cl}_{2}$ mixture to give $\mathbf{1 1}$ as dark yellow crystals (yield: $30 \%$ ) and $\mathbf{1 2}$ as light yellow crystals (yield: $20 \%$ ). Characterizations of silole 11: Mp: 310 ${ }_{635}^{\circ}{ }^{\circ} \mathrm{C}$. UV-Visible ( $\left.\lambda \max , \mathrm{nm}, \log \varepsilon\right): 255$ (5.46), $399(5.20) .{ }^{1} \mathrm{H}$ NMR $\left(\mathrm{CDCl}_{3}, \delta, \mathrm{ppm}\right): 7.15\left(\mathrm{~d},{ }^{3} J(\mathrm{H}, \mathrm{H})=9 \mathrm{~Hz}, 4 \mathrm{H}\right), 6.96-$ $6.86(\mathrm{~m}, 12 \mathrm{H}), 6.74-6.64(\mathrm{~m}, 12 \mathrm{H}), 6.58(\mathrm{~s}, 4 \mathrm{H}), 0.35(\mathrm{~s}$, $1 \mathrm{H}) .{ }^{13} \mathrm{C} \mathrm{NMR}\left(\mathrm{CDCl}_{3}, \delta, \mathrm{ppm}\right): 155.14,153.86,142.14$, $140.60,139.26,139.15,138.84,137.38,131.46,130.82$, $640130.32,130.25,128.93,127.92,127.82,126.77,126.63$, 
119.72, -3.31. ${ }^{29} \mathrm{Si} \mathrm{NMR}\left(\mathrm{CDCl}_{3}, \delta, \mathrm{ppm}\right):$ 8.09. HRMS (FAB+, m-nitrobenzyl alcohol matrix) $\mathrm{m} / \mathrm{z}$ : calcd for $[M+\mathrm{H}]^{+}$ $\mathrm{C}_{54} \mathrm{H}_{44} \mathrm{Br}_{2} \mathrm{Si}_{2}$ : 906.1348; found: 906.1330. Characterizations of silole 11: the synthesis of this compound was previously ${ }_{645}$ described starting from 1-bromo, 4-iodobenzene. ${ }^{55} \mathrm{Mp}: 224$ ${ }^{\circ} \mathrm{C}$. UV-Visible $(\lambda \max , \mathrm{nm}, \log \varepsilon): 250(5.54), 361(5.23) .{ }^{1} \mathrm{H}$ NMR $\left(\mathrm{CDCl}_{3}, \delta, \mathrm{ppm}\right): 7.28\left(\mathrm{~d},{ }^{3} J(\mathrm{H}, \mathrm{H})=9 \mathrm{~Hz}, 4 \mathrm{H}\right), 7.10-$ $7.02(\mathrm{~m}, 6 \mathrm{H}), 6.81-6.75(\mathrm{~m}, 8 \mathrm{H}), 0.47(\mathrm{~s}, 1 \mathrm{H}) .{ }^{13} \mathrm{C} \mathrm{NMR}$ $\left(\mathrm{CDCl}_{3}, \delta, \mathrm{ppm}\right): 154.90,141.17,139.04,138.57,131.56$, $650130.78,130.24,128.02,126.94,119.95,-3.52 .{ }^{29} \mathrm{Si}$ NMR $\left(\mathrm{CDCl}_{3}, \delta, \mathrm{ppm}\right):$ 8.23. HRMS (FAB+, m-nitrobenzyl alcohol matrix) $\mathrm{m} / \mathrm{z}$ : calcd for $[M+\mathrm{H}]^{+} \mathrm{C}_{30} \mathrm{H}_{18} \mathrm{Br}_{2} \mathrm{Si}:$ 571.9996; found: 571.9985 .

Preparation of 2,5-[Bis-(4-antrhracen-9-yl-phenyl)]-1,1${ }_{655}$ dimethyl-3,4-diphenyl-silole (B)

A mixture of lithium $(0.055 \mathrm{~g}, 8 \mathrm{mmol})$ and naphthalene $(1.03 \mathrm{~g}, 8 \mathrm{mmol})$ in THF $(15 \mathrm{~mL})$ was stirred at room temperature under argon for $5 \mathrm{~h}$ to form a deep green solution of lithiumnaphthalenide. To the this mixture was added 660 bis(phenylethynyl)dimethylsilane $1(0.50 \mathrm{~g}, 2 \mathrm{mmol})$ in THF $(10 \mathrm{~mL})$. After stirring for $10 \mathrm{~min}$, the reaction mixture was cooled to $0{ }^{\circ} \mathrm{C}$ and $\left[\mathrm{ZnCl}_{2}(\right.$ tmen $\left.)\right]\left(\right.$ tmen $=N, N, N^{\prime}, N^{\prime}-$ tetramethylenediamine $(2.01 \mathrm{~g}, 8 \mathrm{mmol})$ was added, followed by an addition of THF $(20 \mathrm{~mL})$. After stirring for an hour at 665 room temperature, a solution of 9-(4-bromophenyl)anthracene $3^{34}(1.59 \mathrm{~g}, 4.8 \mathrm{mmol})$ in THF $(20 \mathrm{~mL})$ and $\left[\mathrm{PdCl}_{2}\left(\mathrm{PPh}_{3}\right)_{2}\right](0.10 \mathrm{~g}, 0.13 \mathrm{mmol})$ were successively added. The mixture was heated under reflux and stirred for $20 \mathrm{~h}$. After hydrolysis by water, the mixture was extracted with ${ }_{670} \mathrm{Et}_{2} \mathrm{O}$. After evaporation of the solvents, the resulting residue was subjected to a silicagel column chromatography (pentane $/ \mathrm{CH}_{2} \mathrm{Cl}_{2}: 85 / 15$ ) and recrystallized from an hexane/ $\mathrm{CH}_{2} \mathrm{Cl}_{2}$ mixture to give $\mathbf{B}$ as a yellow crystalline powder (yield: $35 \%)$. Mp : $333{ }^{\circ} \mathrm{C}$. UV-Visible $(\lambda \max , \mathrm{nm}, \log \varepsilon)$ : 675254 (6.37), 352 (5.22), 368 (5.43), 386 (5.50). ${ }^{1} \mathrm{H}$ NMR $\left(\mathrm{CDCl}_{3}, \delta, \mathrm{ppm}\right): 8.51(\mathrm{~s}, 2 \mathrm{H}), 8.07\left(\mathrm{~d},{ }^{3} J(\mathrm{H}, \mathrm{H})=8 \mathrm{~Hz}, 4 \mathrm{H}\right)$, $7.72\left(\mathrm{~d},{ }^{3} \mathrm{~J}(\mathrm{H}, \mathrm{H})=8 \mathrm{~Hz}, 4 \mathrm{H}\right), 7.53-7.37(\mathrm{~m}, 8 \mathrm{H}), 7.28-7.00$ $(\mathrm{m}, 18 \mathrm{H}), 0.77(\mathrm{~s}, 6 \mathrm{H}) .{ }^{13} \mathrm{C} \mathrm{NMR}\left(\mathrm{CDCl}_{3}, \delta, \mathrm{ppm}\right): 155.02$, $146.18,142.73,139.58,139.39,137.53,135.22,133.80$, $680131.31,130.62,130.55,129.18,128.72,127.90,127.33$, $126.81,125.61,125.47,-3.07 .{ }^{29} \mathrm{Si}\left(\mathrm{CDCl}_{3}, \delta, \mathrm{ppm}\right): 2.80 . \mathrm{MS}$ (FAB+, m-nitrobenzyl alcohol matrix) $\mathrm{m} / \mathrm{z}: 766 \quad[M]^{+}$. Analysis calcd for $\mathrm{C}_{58} \mathrm{H}_{42} \mathrm{Si}: 90.82 \% \mathrm{C}, 5.52 \% \mathrm{H}$; found: $89.94 \% \mathrm{C}, 5.64 \% \mathrm{H}$.

\section{${ }_{685}$ Preparation of Silole A'}

Same procedure as for silole $\mathbf{B}$, using a solution of $\mathrm{p}$ 2,2'dipyridylaminophenyl-4-bromophenylether $\mathbf{6}^{50}$ (1.87 g, $4.4 \mathrm{mmol})$ in THF $(20 \mathrm{~mL})$. After evaporation of the solvents, the resulting residue was firstly subjected to a silicagel 690 column chromatography $\left(\mathrm{MeOH} / \mathrm{CH}_{2} \mathrm{Cl}_{2}: 3 / 97\right)$ followed by an alumina column (THF/ $\mathrm{CH}_{2} \mathrm{Cl}_{2}: 5 / 95$ to give $\mathbf{A}^{\prime}$ as a bright yellow powder (yield: $42 \%$ ). Mp: $128^{\circ} \mathrm{C}$. UV-Visible ( $\lambda \max$, $\mathrm{nm}, \log \varepsilon): 277$ (5.70), 377 (5.20). ${ }^{1} \mathrm{H}$ NMR $\left(\mathrm{CDCl}_{3}, \delta, \mathrm{ppm}\right)$ : $8.35\left(\mathrm{dd},{ }^{3} \mathrm{~J}(\mathrm{H}, \mathrm{H})=6,{ }^{3} \mathrm{~J}(\mathrm{H}, \mathrm{H})=2 \mathrm{~Hz}, 4 \mathrm{H}\right), 7.58\left(\mathrm{td},{ }^{3} \mathrm{~J}(\mathrm{H}, \mathrm{H})\right.$ $\left.{ }_{695}=7,{ }^{3} \mathrm{~J}(\mathrm{H}, \mathrm{H})=2 \mathrm{~Hz}, 4 \mathrm{H}\right), 7.16\left(\mathrm{~d},{ }^{3} \mathrm{~J}(\mathrm{H}, \mathrm{H})=9 \mathrm{~Hz}, 4 \mathrm{H}\right), 7.14-$ $6.86(\mathrm{~m}, 30 \mathrm{H}), 0.52(\mathrm{~s}, 6 \mathrm{H}) \cdot{ }^{13} \mathrm{C} \mathrm{NMR}\left(\mathrm{CDCl}_{3}, \delta, \mathrm{ppm}\right)$ : $158.13,155.05,154.67,153.77,148.47,140.48,139.84$,
$138.88,137.50,135.11,132.16,132.06,128.86,127.53$, $126.28,119.69,118.68,117.98,116.66,-3.60 .{ }^{29} \mathrm{Si}$ NMR $700\left(\mathrm{CDCl}_{3}, \delta, \mathrm{ppm}\right):$ 7.87. MS (FAB+, m-nitrobenzyl alcohol matrix) $\mathrm{m} / \mathrm{z}$ : $937[M+\mathrm{H}]^{+}$. Analysis calcd for $\mathrm{C}_{62} \mathrm{H}_{48} \mathrm{~N}_{6} \mathrm{O}_{2} \mathrm{Si}$ : $79.46 \% \mathrm{C}, 5.16 \% \mathrm{H}, 8.97 \% \mathrm{~N}$; found : $78.18 \% \mathrm{C}, 5,34 \% \mathrm{H}$, $8.81 \% \mathrm{~N}$.

Preparation of 2,5-Bis-[4-(4-anthracen-9-yl-phenoxy)705 phenyl]1,1-dimethyl-3,4-diphenyl-silole (B')

Same procedure as for silole $B$, using a solution of $\mathbf{4}$ $(2.04 \mathrm{~g}, 4.8 \mathrm{mmol})$ in THF $(20 \mathrm{~mL})$. After evaporation of the solvents, the resulting residue was firstly subjected to a silicagel column chromatography (pentane $/ \mathrm{CH}_{2} \mathrm{Cl}_{2}: 80 / 20$ ) 710 and recrystallized from hexane $/ \mathrm{CH}_{2} \mathrm{Cl}_{2}$ to give B' as a yellow powder (yield: $89 \%$ ). Mp: $264{ }^{\circ} \mathrm{C}$. UV-Visible ( $\lambda$ max, nm, $\log \varepsilon): 257$ (6.47), 350 (4.95), 362 (5.13), $385(5.10) .{ }^{1} \mathrm{H}$ $\operatorname{NMR}\left(\mathrm{CDCl}_{3}, \delta, \mathrm{ppm}\right): 8.54(\mathrm{~s}, 2 \mathrm{H}), 8.09\left(\mathrm{~d},{ }^{3} \mathrm{~J}(\mathrm{H}, \mathrm{H})=8 \mathrm{~Hz}\right.$, $4 \mathrm{H}), 7.76\left(\mathrm{~d},{ }^{3} \mathrm{~J}(\mathrm{H}, \mathrm{H})=8 \mathrm{~Hz}, 4 \mathrm{H}\right), 7.55-7.38(\mathrm{~m}, 12 \mathrm{H}), 7.24$ ${ }_{15}\left(\mathrm{~d},{ }^{3} \mathrm{~J}(\mathrm{H}, \mathrm{H})=8 \mathrm{~Hz}, 4 \mathrm{H}\right), 7.12-76.90(\mathrm{~m}, 18 \mathrm{H}), 062(\mathrm{~s}, 6 \mathrm{H}) \cdot{ }^{13} \mathrm{C}$ $\mathrm{NMR}\left(\mathrm{CDCl}_{3}, \delta, \mathrm{ppm}\right): 157.18,155.30,154.27,140.97$, $139.39,136.84,135.57,133.75,132.95,131.81,130.83$, $130.77,130.44,128.79,128.00,127.21,127.01,126.73$, $125.79,125.53,119.21,118.94,-3.10 .{ }^{29} \mathrm{Si} \mathrm{NMR}\left(\mathrm{CDCl}_{3}, \delta\right.$, $720 \mathrm{ppm})$ : 7.99. MS (FAB+, m-nitrobenzyl alcohol matrix) $\mathrm{m} / \mathrm{z}$ : $951[M+\mathrm{H}]^{+}$. Analysis calcd for $\mathrm{C}_{70} \mathrm{H}_{50} \mathrm{O}_{2} \mathrm{Si}: 88.39 \% \mathrm{C}, 5.30$ $\% \mathrm{H}$; found : $86.69 \% \mathrm{C}, 5,48 \% \mathrm{H}$.

Preparation of [5-(1,1-dimethyl-3,4-diphenyl-silol-2,5yl)]bis(N,N,N',N'-tetra-pyridin-2-yl-benzene-1,3-diamine) (C)

725 Same procedure as for silole $\mathbf{B}$, using a solution of 3,5bis(2,2'-dipyridylamino)bromobenzene ${ }^{36} 5$ (1.43 g, $\left.4.4 \mathrm{mmol}\right)$ in THF $(20 \mathrm{~mL})$. After evaporation of the solvents, the resulting residue was subjected to a silicagel column chromatography $\left(\mathrm{MeOH} / \mathrm{CH}_{2} \mathrm{Cl}_{2}: 10 / 90\right)$ and recrystallized 730 from an hexane/ $\mathrm{CH}_{2} \mathrm{Cl}_{2}$ mixture to give $\mathbf{C}$ as a bright yellow powder (yield: $28 \%$ ). Mp: $135-137{ }^{\circ} \mathrm{C}$. UV-Visible ( $\lambda \max$, $\mathrm{nm}, \log \varepsilon): 282$ (5.80), 303 (5.79), 379 (5.10). ${ }^{1} \mathrm{H}$ NMR $\left(\mathrm{CDCl}_{3}, \delta, \mathrm{ppm}\right): 8.31\left(\mathrm{dd},{ }^{3} J(\mathrm{H}, \mathrm{H})=6,{ }^{3} J(\mathrm{H}, \mathrm{H})=2 \mathrm{~Hz}, 8 \mathrm{H}\right)$, $7.53\left(\mathrm{td},{ }^{3} \mathrm{~J}(\mathrm{H}, \mathrm{H})=7,{ }^{3} \mathrm{~J}(\mathrm{H}, \mathrm{H})=2 \mathrm{~Hz}, 8 \mathrm{H}\right), 6.92-6.82(\mathrm{~m}$, $73522 \mathrm{H}), 6.72-6.66(\mathrm{~m}, 6 \mathrm{H}), 6.51\left(\mathrm{~d},{ }^{3} J(\mathrm{H}, \mathrm{H})=2 \mathrm{~Hz}, 4 \mathrm{H}\right), 0.27$ (s, 6H). ${ }^{13} \mathrm{C}$ NMR $\left(\mathrm{CDCl}_{3}, \delta, \mathrm{ppm}\right): 157.56,154.46,148.20$, $145.25,142.38,141.19,138.25,137.76,120.51,127.41$, $126.16,123.49,121.87,118.33,117.24,-4.11 .{ }^{29} \mathrm{Si} \mathrm{NMR}$ $\left(\mathrm{CDCl}_{3}, \delta, \mathrm{ppm}\right):$ 8.67. MS (FAB+, m-nitrobenzyl alcohol 740 matrix) $\mathrm{m} / \mathrm{z}$ : $1091[\mathrm{M}+\mathrm{H}]^{+}$. Analysis calcd for $\mathrm{C}_{70} \mathrm{H}_{54} \mathrm{~N}_{12} \mathrm{Si}$ : $77.03 \% \mathrm{C}, 5.16 \% \mathrm{H}, 15.40 \% \mathrm{~N}$; found : $76.56 \% \mathrm{C}, 5.37 \% \mathrm{H}$, $15.99 \% \mathrm{~N}$.

Preparation of (10-[4-(1,1-Dimethyl-3,4-diphenyl-silol-2,5yl)phenyl]-anthracen-9-yl)-bis-(dipyridin-2-yl-amine) (D) :

745 Same procedure as for silole $\mathbf{B}$, using a solution of $\mathbf{1 0}$ $(2.76 \mathrm{~g}, 4.8 \mathrm{mmol})$ in THF $(20 \mathrm{~mL})$. The residue was purified by silicagel column chromatography $\left(\mathrm{CH}_{2} \mathrm{Cl}_{2} / \mathrm{THF}\right.$ gradient : $80 / 20$ to $70 / 30$ ) and crystallized from an hexane $/ \mathrm{CH}_{2} \mathrm{Cl}_{2}$ mixture to afford $\mathbf{D}$ as a yellow solid (yield: $15 \%$ ). Mp: 376 $750{ }^{\circ} \mathrm{C}$. UV-Visible ( $\left.\lambda \max , \mathrm{nm}, \log \varepsilon\right): 268$ (6.30), 389 (5.57), 407 (5.63). ${ }^{1} \mathrm{H}$ NMR $\left(\mathrm{CDCl}_{3}, \delta, \mathrm{ppm}\right): 8.45\left(\mathrm{dd},{ }^{3} J(\mathrm{H}, \mathrm{H})=6\right.$, $\left.{ }^{3} J(\mathrm{H}, \mathrm{H})=2 \mathrm{~Hz}, 4 \mathrm{H}\right), 7.91-7.86(\mathrm{~m}, 4 \mathrm{H}), 7.77-7.86(\mathrm{~m}, 8 \mathrm{H})$, 7.50-7.39 (m, 16H), 7.28-7.19 (m, 10H), 7.19-7.08 (m, 8H), 
7.05-7.02 (m, 8H), $0.88(\mathrm{~s}, 6 \mathrm{H}) .{ }^{13} \mathrm{C} \mathrm{NMR}\left(\mathrm{CDCl}_{3}, \delta, \mathrm{ppm}\right)$ : $755159.81,159.33,155.16,148.90,144.84,141.53,139.74$, $139.29,138.57,137.56,136.75,136.29,135.81,133.48$, $130.80,130.42,130.33,129.50,128.82,127.85,127.23$, $127.03,125.26,125.14,119.73,118.37,117.15,-4.54 .{ }^{29} \mathrm{Si}$ NMR $\left(\mathrm{CDCl}_{3}, \delta, \mathrm{ppm}\right)$ : 8.27. MS (FAB+, m-nitrobenzyl 760 alcohol matrix) $\mathrm{m} / \mathrm{z}: 1257[\mathrm{M}+\mathrm{H}]^{+}$. Analysis calcd for $\mathrm{C}_{90} \mathrm{H}_{64} \mathrm{~N}_{6} \mathrm{Si}: 85.95 \% \mathrm{C}, 5.09 \% \mathrm{H}, 6.68 \% \mathrm{~N}$; found : 85.12 $\% \mathrm{C}, 5.27 \% \mathrm{H}, 6.56 \% \mathrm{~N}$.

Preparation of (4-[5-((1,1-Dimethyl-3,4-diphenyl)silol-2,5yl)phenyl)-1,1-dimethyl-3,4-diphenyl-silol-2-yl)]-biphenyl-4${ }_{765}$ yl)-bis-(di-pyridin-2-yl-amine) (E)

A mixture of bisilole $11(0.40 \mathrm{~g}, 0.44 \mathrm{mmol}), \mathrm{Pd}\left(\mathrm{PPh}_{3}\right)_{4}$ $(0.05 \mathrm{~g}, 0.044 \mathrm{mmol})$, and toluene $(50 \mathrm{~mL})$ was stirred for 10 min. The boronic acid $13^{39}(0.76 \mathrm{~g}, 26 \mathrm{mmol})$ in $20 \mathrm{~mL}$ of EtOH and $\mathrm{NaOH}(0.18 \mathrm{~g})$ in $20 \mathrm{~mL}$ of $\mathrm{H}_{2} \mathrm{O}$ were subsequently 770 added. The mixture was stirred and refluxed for $72 \mathrm{~h}$ and allowed to cool to room temperature. The water layer was separated and extracted with $\mathrm{CH}_{2} \mathrm{Cl}_{2}$. The combined organic layers were dried over $\mathrm{MgSO}_{4}$, and the solvents were evaporated under reduced pressure. Purification of the crude 775 product was carried out by silicagel column chromatography $\left(\mathrm{CH}_{2} \mathrm{Cl}_{2} / \mathrm{THF}: 85 / 15\right)$ followed by the recrystallization of the solid from a $\mathrm{CH}_{2} \mathrm{Cl}_{2}$ /pentane mixture to afford $\mathrm{E}$ as a dark yellowsolid in $86 \%$ yield. \%). Mp: $334^{\circ} \mathrm{C}$. UV-Visible ( $\lambda$ max, $\mathrm{nm}, \log \varepsilon): 284$ (5.77), 311 (5.79), 419 (5.65). ${ }^{1} \mathrm{H}$ NMR $780\left(\mathrm{CDCl}_{3}, \delta, \mathrm{ppm}\right): 8.41\left(\mathrm{dd},{ }^{3} \mathrm{~J}(\mathrm{H}, \mathrm{H})=6,{ }^{3} \mathrm{~J}(\mathrm{H}, \mathrm{H})=2 \mathrm{~Hz}, 4 \mathrm{H}\right)$, 7.66-7.57 (m, 8H), $7.39\left(\mathrm{~d},{ }^{3} J(\mathrm{H}, \mathrm{H})=8.5 \mathrm{~Hz}, 4 \mathrm{H}\right), 7.24(\mathrm{~d}$, $\left.{ }^{3} J(\mathrm{H}, \mathrm{H})=8.5 \mathrm{~Hz}, 4 \mathrm{H}\right), 7.07-6.96(\mathrm{~m}, 24 \mathrm{H}), 6.88-6.83(\mathrm{~m}$, $4 \mathrm{H}), 6.72(\mathrm{~s}, 4 \mathrm{H}), 0.53(\mathrm{~s}, 12 \mathrm{H}) .{ }^{13} \mathrm{C} \mathrm{NMR}\left(\mathrm{CDCl}_{3}, \delta, \mathrm{ppm}\right)$ : $157.62,154.31,153.68,148.18,141.58,140.80,139.04$, $785139.01,138.96,138.01,137.14,137.05,129.98,129.96$, $129.37,128.56,128.13,127.51,127.41,127.36,126.36$, $126.23,126.15,118.30,116.95,-3.45 .{ }^{29} \mathrm{Si} \mathrm{NMR}\left(\mathrm{CDCl}_{3}, \delta\right.$, ppm) : 7.95. MS (FAB+, m-nitrobenzyl alcohol matrix) $\mathrm{m} / \mathrm{z}$ : $1241[M+\mathrm{H}]^{+}$. Analysis calcd for $\mathrm{C}_{86} \mathrm{H}_{68} \mathrm{~N}_{6} \mathrm{Si}_{2}: 83.18 \% \mathrm{C}$, $7905.51 \% \mathrm{H}, 6.78 \% \mathrm{~N}$; found : $82.43 \% \mathrm{C}, 5.66 \% \mathrm{H}, 6.78 \% \mathrm{~N}$.

\section{Aknowledgements}

We would thanks the French ANR (PSICO project \# ANR07-BLAN-0281-01) and the Région Languedoc-Roussillon for their financial support and for the award of a BDI thesis.

\section{${ }_{795}$ References}

1. C. W. Tang and S. A. VanSlyke, Appl. Phys. Lett., 1987, 51, 913.

2. J. H. Burroughes, D. D. C. Bradley, A. R. Brown, R. N. Marks, K. Mackay, R. H. Friend, P. L. Burns and A. B. Holmes, Nature, 1990, 347, 539 .

800 3. D. F. O'Brien, M. A. Baldo, M. E. Thompson and S. R. Forrest, Appl. Phys. Lett., 1999, 74, 442.

4. M. A. Baldo, S. Lamansky, P. E. Burrows, M. E. Thompson and S. R. Forrest, Appl. Phys. Lett., 1999, 75, 4.

5. S. Lamansky, P. Djurovich, D. Murphy, F. Abdel-Razzaq, H. E. Lee,

805 C. Adachi, P. E. Burrows, S. R. Forrest and M. E. Thompson, J. Am. Chem. Soc., 2001, 123, 4304.

6. S. Welter, K. Brunner, J. W. Hofstraat and L. De Cola, Nature, 2003, 421, 54.

7. C. Borek, K. Hanson, P. I. Djurovich, M. E. Thompson, K. 810 Aznavour, R. Bau, Y. Sun, S. R. Forrest, J. Brooks, L. Michalski and J. Brown, Angew. Chem. Int. Ed., 2007, 46, 1109.
8. M. Cocchi, J. Kalinowski, D. Virgili, V. Fattori, S. Develay and J. A. Williams, J. Appl. Phys., 2007, 90, 163508.

9. A. Fischer, S. Chénais, S. Forget, M.-C. Castex, D. Adès, A. Siove, C. Denis, P. Maisse and B. Geffroy, J. Phys. D : Appl. Phys., 2006, 39, 917.

10. G. Gu, G. Parthasarathy and S. R. Forrest, Appl. Phys. Lett., 1999, 74, 305.

11. J. Birnstock, J. Blochwitz-Nimoth, M. Hofmann, M. Vehse, G. He, P. Wellmann, M. Pfeiffer and K. Leo, IDW Proceedings, 2004, 1265.

12. J. Dubac, C. Guerin and P. Meunier, in The Chemistry of Organic Silicon Compounds, eds. Z. Rappoport and Y. Apeloig, Wiley, Chichester, 1998, vol. 2, pp. 1961-2036.

13. J. Dubac, A. Laporterie and G. Manuel, Chem. Rev. , 1990, 90, 215.

825 14. S. Yamaguchi and K. Tamao, J. Chem. Soc., Dalton Trans., 1998, 22, 3693-3702.

15. J. Chen and Y. Cao, Macromol. Rapid Commun., 2007, 28, 1714.

16. S. Yamaguchi and K. Tamao, Bull. Chem. Soc. Jpn, 1996, 69, 2327.

17. N. Roques, P. Gerbier, U. Schatzschneider, J.-P. Sutter, P. Guionneau, J. Vidal-Gancedo, J. Veciana, E. Rentschler and C. Guérin, Chem. Eur. J., 2006.

18. N. Roques, P. Gerbier, J.-P. Sutter, P. Guionneau, D. Luneau and C. Guérin, Organometallics, 2003, 22, 4833.

19. CSD, Cambridge Structural Database (CSD), (2003).

835 20. J. Chen, C. C. W. Law, J. W. Y. Lam, Y. Dong, S. M. F. Lo, I. D. Williams, D. Zhu and B. Z. Tang, Chem. Mater., 2003, 15, 15351546.

21. Y. Ren, Y. Dong, J. W. Y. Lam, B. Z. Tang and K. S. Wong, Chem. Phys. Lett., 2005, 402, 468.

840 22. H. Murata, Z. H. Kafafi and M. Uchida, Appl. Phys. Lett., 2002, 80, 189.

23. J. Chen, B. Xu, K. Yang, Y. Cao, H. H. Y. Sung, I. D. Williams and B. Z. Tang, J. Phys. Chem. B., 2005, 109, 17086.

24. H. Y. Chen, W. Y. Lam, J. D. Luo, Y. L. Ho, B. Z. Tang, D. B. Zhu, M. Wong and H. S. Kwok, Appl. Phys. Lett., 2002, 81, 574.

25. L. Aubouy, P. Gerbier, N. Huby, G. Wantz, L. Vignau, L. Hirsch and J.-M. Janot, N. J. Chem., 2004, 28, 1086.

26. H. Murata, G. G. Malliaras, M. Uchida, Y. Shen and Z. H. Kafafi, Chem. Phys. Lett., 2001, 339, 161-166.

850 27. N. Huby, G. Wantz, L. Hirsch, L. Vignau, A. S. Barrière, L. Aubouy and P. Gerbier, J. Appl. Phys., 2006, 99, 084907.

28. G. Yu, S. Yin, Y. Liu, J. Chen, X. Xu, X. Sun, D. Ma, X. Zhan, Q. Peng, Z. Shuai, B. Tang, D. Zhu, W. Fang and Y. Luo, J. Am. Chem. Soc., 2005, 127, 6335.

855 29. J. Pang, Y. Tao, S. Freiberg, X.-P. Yang, M. D'Iorio and S. Wang, J. Mater. Chem., 2002, 12, 206.

30. J. Lee, Q.-D. Liu, D.-R. Bai, Y. Kang, Y. Tao and S. Wang, Organometallics, 2004, 23, 6205.

31. K. Danel, T. H. Huang, J. T. Lin, Y. T. Tao and C. H. Chuen, Chem. Mat., 2002, 14, 3860.

32. P. Raghunath, M. A. Reddy, C. Gouri, K. Bhanuprakash and V. J. Rao, J. Phys. Chem. A, 2006, 110, 1152-1162.

33. S. Yamaguchi, T. Endo, M. Uchida, T. Izumizawa, K. Furukawa and K. Tamao, Chem. Eur. J., 2000, 6, 1683-1692.

865 34. S. Murphy, X. Yang and G. B. Schuster, J. Org. Chem., 1995, 60, 2411.

35. F. Kong, X. L. Wu, G. S. Huang, R. K. Yuan, C. Z. Yang, P. K. Chu and G. G. Siu, Appl. Phys. A, 2006, 84, 203-206

36. W.-L. Jai, D.-R. Bai, T. McCormick, Q.-D. Liu, M. Motala, R.-Y. 870 Wang, C. Seward, Y. Tao and S. Wang, Chem. Eur. J. , 2004, 10, 994.

37. M. Smet and W. Dehaen, Molecules, 2000, 5, 620.

38. M. Smet, J. Van Dijk and W. Dehaen, Tetrahedron, 1999, 55, 7859.

39. W.-L. Jia, D. Song and S. Wang, J. Org. Chem., 2003, 68, 701.

875 40. J. Lee, Q.-D. Liu, M. Motala, J. Dane, J. Gao, Y. Kang and S. Wang, Chem. Mat., 2004, 116, 1869-1877.

41. N. Huby, L. Hirsch, L. Aubouy, P. Gerbier, A. van der Lee, F. Amy and A. Kahn, Phys. Rev. B, 2007, 75, 115416.

42. C. Lee, W. Yang and R. G. Parr, Phys. Rev. B, 1988, 37, 785.

880 43. R. A. Gaussian 98, M. J. Frisch, G. W. Trucks, H. B. Schlegel, G. E. Scuseria, M. A. Robb, J. R. Cheeseman, V. G. Zakrzewski, J. A. Montgomery, Jr., R. E. Stratmann, J. C. Burant, S. Dapprich, J. M. 
Millam, A. D. Daniels, K. N. Kudin, M. C. Strain, O. Farkas, J. Tomasi, V. Barone, M. Cossi, R. Cammi, B. Mennucci, C. Pomelli,

C. Adamo, S. Clifford, J. Ochterski, G. A. Petersson, P. Y. Ayala, Q. Cui, K. Morokuma, D. K. Malick, A. D. Rabuck, K. Ragha-vachari, J. B. Foresman, J. Cioslowski, J. V. Ortiz, A. G. Baboul, B. B. Stefanov, G. Liu, A. Liashenko, P. Piskorz, I. Komaromi, R. Gomperts, R. L. Mar-tin, D. J. Fox, T. Keith, M. A. Al-Laham, C. Y. Peng, A.

890 Nanayakkara, M. Challacombe, P. M. W. Gill, B. Johnson, W. Chen, M. W. Wong, J. L. Andres, C. Gonzalez, M. Head-Gordon, E. S. Replogle, and J. A. Pople, Gaussian, Inc., Pittsburgh PA, 1998., (1998).

44. L. Aubouy, N. Huby, L. Hirsch, A. Van der Lee and P. Gerbier, To be published., 2008.

45. H. Du, R. A. Fuh, J. Li, A. Corkan and J. S. Lindsey, Photochem. Photobiol., 1998, 68, 141.

46. S. Yamaguchi and K. Tamao, Bull. Chem. Soc.Jpn., 1996, 69, 2327.

47. C. Risko, G. P. Kushto, Z. H. Kafafi and J. L. Brédas, J. Chem.

900 Phys., 2004, 121, 9031.

48. Y. Shirota and H. Kageyama, Chem. Rev., 2007, 107, 953.

49. K. Walzer, B. Maennig, M. Pefeiffer and K. Leo, Chem. Rev., 2007, 107, 1233.

50. L. Aubouy, P. Gerbier, C. Guérin, N. Huby, L. Hirsch and L. Vignau, Synth. Met., 2007, 157, 91.

51. V. Coropceanu, J. Cornil, D. A. da Silva Filho, Y. Olivier, R. Silbey and L.-L. Bredas, Chem. Rev., 2007, 107, 926.

52. L. Palatinus and G. Chapuis, J. Appl. Cryst., 2007, 40.

53. P. W. Betteridge, J. R. Carruthers, R. I. Cooper, K. Prout and D. J. Watkin, J. Appl. Cryst., 2003, 36, 1487.

54. A. V. Dijken, A. Perro, E. A. Meulenkamp and K. Brunner, Organic Electronics, 2003, 4, 131-141.

55. F. Wang, J. Luo, J. Chen, F. Huang and Y. Cao, Polymer, 2005, 46, 8422. 
$\longrightarrow$ 